\title{
Uncertainty in surface-fire history: the case of ponderosa pine forests in the western United States
}

\author{
William L. Baker and Donna Ehle
}

\begin{abstract}
Present understanding of fire ecology in forests subject to surface fires is based on fire-scar evidence. We present theory and empirical results that suggest that fire-history data have uncertainties and biases when used to estimate the population mean fire interval (FI) or other parameters of the fire regime. First, the population mean FI is difficult to estimate precisely because of unrecorded fires and can only be shown to lie in a broad range. Second, the interval between tree origin and first fire scar estimates a real fire-free interval that warrants inclusion in mean-FI calculations. Finally, inadequate sampling and targeting of multiple-scarred trees and high scar densities bias mean FIs toward shorter intervals. In ponderosa pine (Pinus ponderosa Dougl. ex P. \& C. Laws.) forests of the western United States, these uncertainties and biases suggest that reported mean FIs of 2-25 years significantly underestimate population mean FIs, which instead may be between 22 and 308 years. We suggest that uncertainty be explicitly stated in fire-history results by bracketing the range of possible population mean FIs. Research and improved methods may narrow the range, but there is no statistical or other method that can eliminate all uncertainty. Longer mean FIs in ponderosa pine forests suggest that $(i)$ surface fire is still important, but less so in maintaining forest structure, and (ii) some dense patches of trees may have occurred in the pre-Euro-American landscape. Creation of low-density forest structure across all parts of ponderosa pine landscapes, particularly in valuable parks and reserves, is not supported by these results.
\end{abstract}

Résumé : La compréhension actuelle de l'écologie du feu dans les forêts sujettes aux feux de surface repose sur la présence des cicatrices laissées par le feu. Nous présentons des résultats théoriques et empiriques qui montrent que les données sur l'historique des feux comportent des incertitudes et des biais lorsqu'elles sont utilisées pour estimer l'intervalle moyen entre les feux ou d'autres paramètres du régime des feux. Premièrement, il est difficile d'estimer avec précision l'intervalle moyen entre les feux à cause des feux qui ne sont pas comptabilisés et cette valeur a donc forcément un fort coefficient de variation. Deuxièmement, l'intervalle entre l'apparition des arbres et la détection des premières cicatrices constitue un intervalle réel pendant lequel il n'y pas eu de feu et doit être inclus dans le calcul de l'intervalle moyen entre les feux. Finalement, un échantillonnage inadéquat, des arbres avec des cicatrices multiples et une densité élevée de cicatrices introduisent des biais qui entraînent une sous-estimation de l'intervalle entre les feux. Dans les forêts de pin ponderosa (Pinus ponderosa Dougl. ex P. \& C. Laws.) de l'ouest des États-Unis, ces incertitudes et ces biais suggèrent une forte sous-estimation des intervalles moyens entre les feux qui pourraient se situer entre 22 et 308 ans plutôt qu'entre 2 et 25 ans tel que rapporté. Nous suggérons que l'incertitude soit explicitement mentionnée dans les résultats qui réfèrent à l'historique des feux en indiquant une fourchette d'intervalles moyens entre les feux. La recherche et de meilleures méthodes pourraient réduire l'écart mais il n'y a pas de méthodes statistiques ou autres capables d'éliminer toute incertitude. Des intervalles moyens entre les feux plus longs dans les forêts de pin ponderosa indiquent que (i) les feux de surface sont encore importants, mais pas autant pour maintenir la structure de la forêt et (ii) des îlots denses d'arbres ont pu exister dans le paysage avant l'arrivée des européens. Ces résultats ne supportent pas la pratique qui consiste à maintenir une structure caractérisée par une faible densité partout dans le paysage occupé par le pin ponderosa, particulièrement dans les zones qui ont une grande valeur, comme les parcs et les réserves.

[Traduit par la Rédaction]

\section{Introduction}

Forests have been altered by human modifications of natural disturbance regimes, and restoration of forest structure and disturbance processes is increasingly a goal of manage-

Received May 25, 2000. Accepted February 16, 2001.

Published on the NRC Research Press Web site at http://cjfr.nrc.ca on June 25, 2001.

W.L. Baker ${ }^{1}$ and D. Ehle. Department of Geography and Recreation University of Wyoming Laramie, WY 82071, U.S.A.

${ }^{1}$ Corresponding author (e-mail: bakerwl@uwyo.edu). ment. Ponderosa pine (Pinus ponderosa Dougl. ex P. \& C. Laws.) forests of the western United States, for example, are thought to be modified by fire exclusion, leading to fuel buildup and higher tree density that may increase the probability of stand-replacing fires (Covington and Moore 1992, $1994 a, 1994 b)$. Restoration of pre-Euro-American tree density and reintroduction of fire are considered remedies for this condition (Covington et al. 1997). In this paper we argue that the fire-history basis for these ideas is uncertain.

Fire-history research has focused on fire intervals, particularly the mean fire interval (mean FI), as essential to the description and comparison of surface-fire regimes and one of the frames of reference for restoration. Yet, mean FI and 
Table 1. Some possible reasons that a living tree inside a fire perimeter may not have a scar from the fire.

No fire sufficiently near the trunk (unburned area)

Bare or rocky soil or patches of rock with little or no fuel

Little or no fuel for other reasons

Fuel moisture too high to carry a fire nearby

Sufficient fuel, but no connectivity to the spreading flame front

Wind fluctuations cause the fire to shift away

Insufficient fire intensity to scar the trunk

Fire intensity too low

Insufficient fuel

Fuel moisture too high

Heat not directed at the trunk, due to wind shifts

High fire intensity directed at trunk, but trunk resistant to scarring

No previous scars, wounds, or fissures

Bark sufficiently thick to resist heat load

other fire-interval parameters (e.g., median, maximum, range) can be sampled, quantified, and summarized using several methods. There has been little research on the effects of variation in these methods (but see McBride 1983; Agee 1993; Johnson and Gutsell 1994) or on their reliability in reconstructing past fire history. A sampled fire-scar record, for example, is not free of uncertainty or potential bias. It is uncertain, for example, whether a tree without a scar did or did not burn in a fire that scarred nearby trees. Moreover, the method of selecting samples of fire-scarred trees affects to what extent the sample is an adequate and unbiased estimator of the parameters (e.g., mean FI) of a fire regime (Johnson and Gutsell 1994).

A modern calibration, to test how the fire-scar record should be sampled and interpreted to reconstruct the past fire regime, has never been attempted, so far as we are aware. While fire-history methods may rely upon concepts that have a logical basis, modern calibrations are essential to verify that these concepts are reliable for quantitative paleoecological research (e.g., Clark 1988). This calibration research would be difficult for fires, since they are infrequent. However, we argue that until this essential calibration research can be completed, potential uncertainties and biases should be explicitly considered and incorporated into firehistory results. Present methods can also be revised to minimize known biases, such as from purposive sampling (Johnson and Gutsell 1994).

Our focus is on nearly pure ponderosa pine forests, excluding mixed conifer forests sometimes referred to as ponderosa pine forests because of ponderosa pine dominance. We focus our analysis on the mean FI primarily because this parameter is the only one widely reported in the literature, allowing us to compare many studies, rather than because mean FI is the only important or best parameter of the fire regime. The simple median or Weibull median of a set of fire intervals, for example, may better reflect central tendencies in non-normal fire-interval distributions (GrissinoMayer 2000). We first review the theory and practice of calculating and analyzing fire intervals in surface-fire regimes using fire-scar data. Then, we turn to the specific case of ponderosa pine forests, before drawing our arguments together, and discussing the implications.

\section{Theory and practice of calculating and analyzing fire intervals using fire-scar data}

\section{Fire-scar formation, unrecorded fires, and the uncertainty of a tree without a scar}

Fire scars form most commonly on the leeward side of trees burned in head fires, as a result of longer duration and greater heat load on the bark (Fahnestock and Hare 1964; Gill 1974; Gutsell and Johnson 1996). Occurrence of previous open wounds encourages re-scarring and may lead to wound expansion (Lachmund 1923), and fuels near the base may increase scar formation (Show and Kotok 1924). Resistance to scarring is approximately proportional to the square of the bark thickness, so larger and older trees are much more resistant (Vines 1968).

Trees are often charred by a surface fire, but fires do not always leave scars in particular areas or even a whole stand, so fires may be unrecorded in fire scars. Show and Kotok (1924) suggest that, once a tree is scarred, it subsequently records even low-intensity fires. However, trees are commonly charred but not scarred (e.g., Sherman 1969), although trees that appear to be merely charred may later reveal a scar (Fahnestock and Hare 1964). Shallow scars may also be burned away by subsequent fires. Thus, an individual tree may contain an imperfect record of the fires that burned near the tree, but how imperfect is this record?

The abundance of unrecorded fires is largely unknown. Fire researchers may have strong intuition about how common unrecorded fires are in particular places, but there is little quantitative information based on systematic research. Lachmund (1923) found that $9 \%$ of ponderosa pines burned by a single fire had new scars, but light surface fires can leave $20 \%$ or more of the trees scarred (Morris and Mowat 1958). This does not mean that $80 \%$ or $91 \%$ of trees may fail to record a light surface fire, because there are other reasons for the absence of a scar.

There are several reasons that a tree inside a fire perimeter may lack a scar (Table 1). Chief among these is that some areas within the perimeter did not receive flames from the fire. Because of unburned area inside fire perimeters, a tree without a scar is always ambiguous, as it may or may not have burned in a fire that burned neighboring trees. From studies in ponderosa pine, reviewed later, unburned area can be $10-58 \%$ of the area inside the burn perimeter. More study is needed of unburned area inside fire perimeters and the rate of scarring of the fraction of trees that did receive flames. Without modern calibration, the problem of unrecorded fires means that fire-scar records provide uncertain estimates of fire-regime parameters, such as the mean FI.

\section{The fire rotation, population mean fire interval, and estimated mean fire interval}

We suggest that one goal of fire-history research should be to estimate the population mean FI and fire rotation for a stand (homogeneous area of forest up to several hundred hectares in area) or for other areas of interest. What are the relationships of the fire rotation, the population mean FI, and the fire interval estimated from a sample of scarred trees? We use a hypothetical example to illustrate these relationships (Fig. 1). This example is of a 100-ha stand in which three fires occur after an initial fire in $1700 \mathrm{AD}$. The fires 
Fig. 1. The relationship between fire rotation, the population mean fire interval, and the sample mean fire interval for a hypothetical 100-ha stand divided into four quarters. The hypothetical stand was burned by three fires after 1700 AD.

\section{Spatial and Temporal Extent}

\section{Fires}

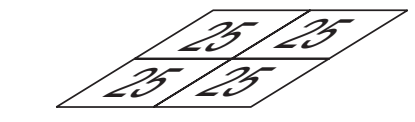

a. Area (ha)
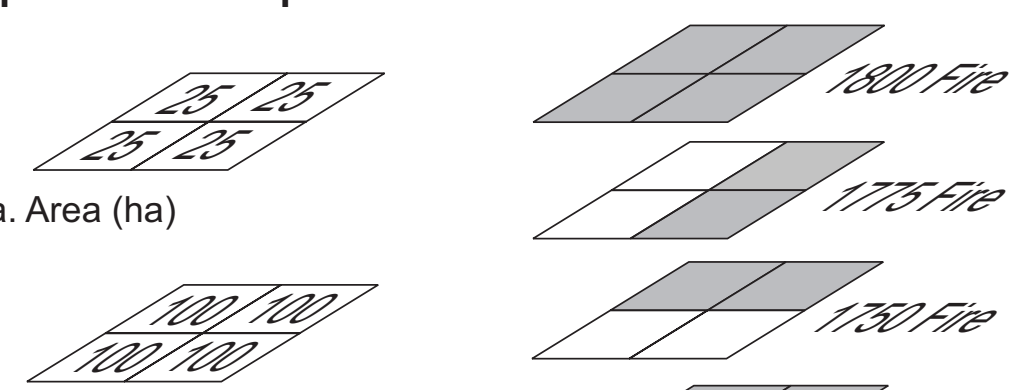

b.Time Interval (years)

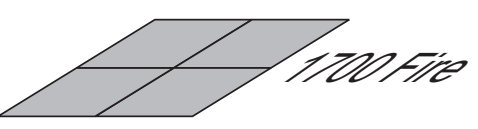

\section{Fire Rotation}

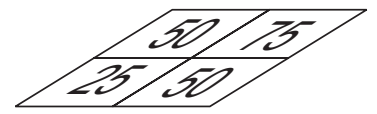

c. area burned per 100 years (ha)

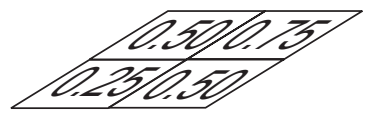

d. Mean area burned per year $(h a)=c / b$

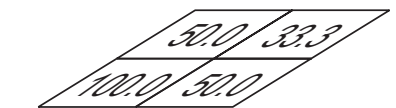

e. fire rotation $($ years $)=a / d$

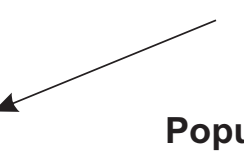

Population Mean Fire Interval

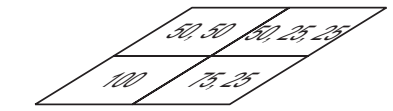

f. fire intervals (years) - each area

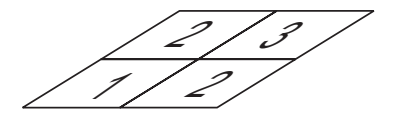

g. number of fire intervals - each area

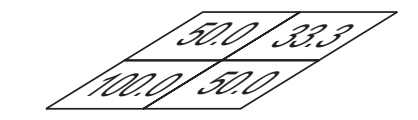

h. population mean $\mathrm{FI}$ (years) $=\mathrm{b} / \mathrm{g}$
Sample Mean Fire Interval

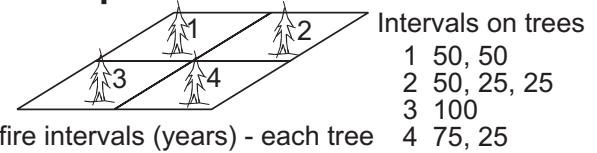

i. fire intervals (years) - each tree 475,25

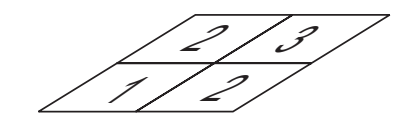

j. number of fire intervals - each tree

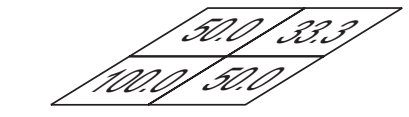

k. sample mean FI (years) $=$ b/k burn all of 50, 50, and 100 ha for a total of 200 ha in 100 years, an average of $2 \mathrm{ha} /$ year.

The fire rotation is defined as the time required to burn an area equal to the area of interest (Romme 1980), in this case the 100-ha stand. Fire rotation is often used to describe stand-replacing fire regimes but is equally relevant to surface-fire regimes, since in both cases fires burn over a certain land area (Romme 1980). The fire rotation for the example stand (Fig. 1) is 100 ha divided by 2 ha/year, which equals 50 years. If the fire rotation is 50 years, then about $2 \%$ of the area, on average, should burn each year, and the whole area should burn roughly every 50 years. However, much of the burning during a rotation may occur in a few fire years, with little or no area burned in most years (Strauss et al. 1989). Moreover, if the fire rotation for a study area is 50 years, there may be considerable spatial variability in fire rotations among smaller parts of the study area (Fig. 1e). Fire-rotation calculation is illustrated for the four quarters of the hypothetical stand (Figs. 1c-1e). If some parts of a study area have fire rotations longer than 50 years, then other parts must have rotations less than 50 years for the rotation for the whole study area to be equal to 50 years. The typical approach to estimate the fire rotation is to sum up the areas of individual past fires, but it is difficult to estimate the size of past fires in surface-fire regimes because of the common absence of conspicuous changes in stand structure at surface-fire boundaries.
It has not been generally recognized that the population mean FI is equal to the fire rotation (but see McKelvey et al. 1996), but this makes it possible to estimate the fire rotation without knowing fire sizes. In our hypothetical example, we have maps of the fires, so we can calculate the exact fire intervals for each of the four quarters (Fig. 1f), and then count up how many fire intervals there were in each quarter during the 100-year interval from 1700 to 1800 AD (Fig. $1 g$ ). The length of time is divided by the number of intervals to obtain the population mean FI for each quarter (Fig. 1h). For the four quarters, the population mean FI is identical to the fire rotation (Figs. 1e and $1 h$ ).

This identity between the fire rotation and the population mean FI can be understood in a more general way. On average, each square metre or any other areal unit of a study area will experience one fire during a fire rotation, as the fire rotation is defined as the time needed to burn over an area equal to that of a particular area of interest a single time (Romme 1980). It follows that, on average, each square metre will receive the next fire after another fire rotation. Then, it is a simple deduction that the mean interval between fires, averaged across all square metres in a land area, must be equal to the fire rotation for the land area. Regardless of the land area, the fire rotation for that area is identical to the population mean FI, as these two measures are simply contrasting spatial and temporal derivations of the rate of burning. 
Table 2. A hypothetical example illustrating the use of fire-scar data to estimate standlevel fire parameters.

\begin{tabular}{lllllll}
\hline & \multicolumn{2}{l}{ Tree No. } & & & \\
\cline { 2 - 5 } Year & 1 & 2 & 3 & 4 & 5 & Composite \\
\hline 1900 & $\mathrm{X}$ & $\mathrm{X}$ & $\mathrm{X}$ & $\mathrm{X}$ & 0 & $\mathrm{X}$ \\
1899 & 0 & 0 & 0 & 0 & 0 & 0 \\
1898 & 0 & 0 & 0 & 0 & 0 & 0 \\
1897 & 0 & 0 & 0 & 0 & 0 & 0 \\
1896 & 0 & $\mathrm{X}$ & 0 & 0 & $\mathrm{X}$ & $\mathrm{X}$ \\
1895 & 0 & 0 & 0 & 0 & 0 & 0 \\
1894 & 0 & 0 & 0 & 0 & 0 & 0 \\
1893 & 0 & 0 & 0 & $\mathrm{X}$ & $\mathrm{X}$ & $\mathrm{X}$ \\
1892 & 0 & 0 & 0 & 0 & 0 & 0 \\
1891 & 0 & $\mathrm{X}$ & $\mathrm{X}$ & 0 & 0 & $\mathrm{X}$ \\
1890 & $\mathrm{X}$ & 0 & 0 & $\mathrm{X}$ & 0 & $\mathrm{X}$ \\
Fire intervals (years) & 10 & 4 & 9 & 7 & 3 & 4 \\
& & 5 & & 3 & & 3 \\
& & & & & & 2 \\
No. of intervals & 1 & 2 & 1 & 2 & 1 & 4 \\
Mean interval (years) & 10.0 & 4.5 & 9.0 & 5.0 & 3.0 & Mean composite FI = 2.5 \\
& & & & & & Mean individual-tree FI = 5.9
\end{tabular}

Note: An X indicates a fire-scar is present from that year, while a 0 indicates a fire-scar is not present. Fire-scar intervals at the bottom of the table are only scar-to-scar intervals. Mean individualtree FI is the weighted mean of the mean intervals for the five trees.

Now consider that trees, and the fire scars they contain, are similar to any other areal unit. However, fire-scarred trees typically contain only a sample, not the population, of fire intervals, since not all scarred trees may be sampled, and unrecorded fires occur. If all fires were recorded in the scars, an adequate sample from scars would accurately estimate the population mean FI and fire rotation. In our hypothetical example, we illustrate this by showing that, if four trees, one in each quarter, each contain a record of all the fires that burned in that quarter, then just these four trees can precisely estimate the population mean FI and fire rotation for the stand (Figs. $1 i, 1 j$, and $1 k$ ).

It is inappropriate to calculate the mean of the fire rotations or the mean FI for the four quarters (Fig. 1e), which is 58.3 years, to find the mean fire rotation or mean FI for the whole stand, which is 50.0 years. To find the mean fire rotation or mean FI for the whole stand from values in the four quarters, a weighted mean is needed. The weights are the number of rotations or number of intervals in the time interval of interest (100 years in this case). Thus, the mean fire rotation and mean FI for the whole study area are both calculated from fire rotations and mean FIs in the four quarters (Figs. $1 d$ and $1 g)$ as $((2 \times 50.0)+(3 \times 33.3)+(1 \times 100.0)+$ $(2 \times 50.0)) / 8=50.0$ years.

Of course, our hypothetical example is also quite simple and ideal. In reality, fires are irregular in shape, and fire scars on trees do not record all the fires. Thus, we turn to the problem of estimating the population mean FI from a set of fire-scar samples.

\section{How are stand-level fire-regime parameters calculated and what do they mean?}

It is common practice today to produce a composite (Dieterich 1980a) or master fire chronology (Grissino-Mayer 1995) for a stand or site from a sample of fire-scarred trees, but some authors also report fire intervals for individual trees or the mean from a group of trees. We illustrate these two alternative treatments of fire-scar data in a hypothetical stand (Table 2). In the individual-tree approach the list of fire intervals for each tree is first calculated, then the mean for all the intervals on a particular tree is calculated. Individual-tree mean FIs are then averaged among all the trees sampled in a stand, weighted by the number of intervals, to estimate the mean individual-tree FI. In the example, the mean individualtree FI is 5.9 years. In contrast, mean composite FI, summarized along the right side of the table, is calculated by first creating a master chronology or composite that lists every fire found on sampled trees. The set of fire intervals and parameters is then calculated from the composite. In the example, the mean composite FI is 2.5 years. The important distinction is whether actual intervals from individual trees are used (individual-tree approach) or intervals are created from a list of compiled fire years (composite approach of Dieterich 1980a).

How are the mean individual-tree FI and mean composite FI to be interpreted? The mean individual-tree FI, in a sense, can be interpreted to be a minimum fire assumption; the only trees assumed to actually have burned in a particular fire are those that contain a scar dating to the fire. There is no correction or adjustment for unrecorded fires. The mean individual-tree FI, thus, is uncertain, as it may overestimate the length of the population mean FI if there are unrecorded fires, and the magnitude of unrecorded fires is unknown. The composite FI assumption, in a sense, is a maximum fire assumption, as each fire scar may be assumed to represent a fire that generally burned the entire stand, although fuel discontinuities may leave some unburned area inside the fire perimeter (e.g., Dieterich 1980b). The composite column contains an $\mathrm{X}$ if any tree experienced a fire (Table 2), consistent with this interpretation. The composite FI also implies 
that the fire-scar record on many trees is incomplete because of unrecorded fires and aims to offset unrecorded fires by compositing (Dieterich 1980a). The mean composite FI, however, underestimates the length of the population mean FI if there really are few unrecorded fires. However, because the magnitude of unrecorded fires is unknown, the composite FI now more typically has an equivocal fire interpretation, meaning only that a fire burned somewhere in the stand or site, not necessarily the whole area, after the composite FI. This interpretation recognizes that fires are spatially patchy, often not burning the entire stand (Arno and Petersen 1983; Barrett 1988; Goldblum and Veblen 1992). Individual-tree FIs and composite FIs thus have different but compatible meanings. In the example (Table 2), trees may have a mean individual-tree FI of 5.9 years at the same time that fire occurs somewhere in the stand as a whole once every 2.5 years (mean composite FI).

The individual-tree FI is uncertain and the composite FI equivocal, so neither is likely to be equal to the population mean FI for the stand. At first glance, it may seem that, when unrecorded fires are common, the composite FI estimate may be closer to the population mean FI, but when unrecorded fires are rare, the individual-tree FI estimate is likely closer to the population mean FI. It could be argued that the composite FI is not intended to estimate the population mean FI, as it explicitly recognizes the equivocal nature of the fire record. However, we suggest that the composite FI makes comparison of fire intervals difficult, since composite FI varies with spatial extent. Because of its equivocal nature, it is also not very useful in understanding the spatial ecology of fire or in providing guidance for land managers.

\section{Problems with the composite FI}

Each fire, whether small or large, potentially decreases the value of the composite FI by the same amount, while small fires only affect the individual-tree FI value for the one to few trees scarred by the fire. Small fires may be common in ponderosa pine forests, as evidenced by the small number of fire scars that document most fire years (Fig. 2). Lightning strikes, for example, may produce insignificant fires that scar only one or just a few ponderosa pines (Taylor 1969). On average, $72.4 \%$ of identified fire years, in an available sample of ponderosa pine stands we obtained from the literature, are documented by only one or two fire scars (Fig. $2 l$ ). For most studies a high percentage of fire years is documented by only one or two scarred trees. In some cases, few scars documenting a fire may result from a low scarring rate, but small fires appear to be common.

In part to offset the potential impact of numerous small fires, some authors calculate a restricted composite FI, in which compositing is restricted to only those fires that scar $10 \%, 25 \%$, some other percentage, or a minimum number of the sampled trees (e.g., Grissino-Mayer 1995; Brown and Sieg 1996; Swetnam and Baisan 1996a, 1996b; Veblen et al. 2000). Fisher et al. (1987), for example, ignore spot fires (scarring only one tree or a small group of trees) and calculate the mean interval between only the area-wide fires that affect much of the landscape.

To assess the impact of percentage restrictions on mean composite FI, we used data for 32 ponderosa pine stands (Grissino-Mayer 1995, $n=$ 9; Swetnam and Baisan 1996a, $n=21$; Swetnam and Baisan 1996b, $n=2$ ) where mean composite FI, based on all scarred trees, $>10 \%$ scarred, and $>25 \%$ scarred, is reported. In this sample, mean composite FI for all scarred trees is 7.5 years, while it is 13.4 years for the $>10 \%$ scarred class and 15.1 years for the $>25 \%$ scarred class. The arbitrary choice of how much restriction to use thus has a large influence on the value of the mean composite FI, but restriction does lead to a composite FI estimate that better reflects larger fires that affect more land area.

While a restricted composite FI may partially offset the problem of small fires, the composite FI has other problems that outweigh this benefit. First, the equivocal interpretation of the composite FI means that it is not suitable as an estimator of the population mean FI and fire rotation for the study area. Second, mean composite FI declines as study area size increases and more fires are found (Arno and Petersen 1983). Managers will seldom be able to find a composite FI estimate for a study area of about the same size as the area they plan to burn or are managing, yet this is essential if the composite FI value is to be used as a guide. The population mean FI and mean individual-tree FI, in contrast, have no particular trend as study area size increases. Managers using prescribed fire are seldom able to simply set a fire somewhere in a study area and let it burn as it will, yet this would be compatible with the equivocal meaning of the composite FI. Prescribed fires instead take place under controlled conditions in which the fire is planned to burn until it reaches pre-determined limits. The more relevant information for fire managers is how often an area should be burned, how much land area to burn each year, or how often, on average, each tree should be burned. Information about the spatial variability of fire also is needed. This information is also essential to understanding the spatial ecology of fires.

\section{Bracketing uncertainty due to unrecorded fires}

It would be ideal to be able to correct fire-interval estimates for unrecorded fires. Unfortunately, methods of correcting for unrecorded fires have been proposed but rest on untested or invalid assumptions. Dieterich's (1980a, 1980b) method assumes that each susceptible tree in a stand actually was burned by every fire that burned in the stand. This is the maximum fire assumption that is not supported by available evidence. There are burned and unburned areas inside fire perimeters (e.g., Sackett 1980), so it cannot be assumed that unscarred trees adjacent to a fire-scarred tree also were burned. To truly overcome the uncertainty of trees without scars, and to estimate scarring rates, empirical observation of natural fires is necessary.

Until research can resolve or narrow the problem of unrecorded fires, a logical recourse is to explicitly estimate the possible range of the present uncertainty. We suggest as a starting point that, except for correction for other problems explained later, the mean individual-tree FI and the restricted mean composite FI may span the limits within which the population mean FI lies, for the following reasons. If there are no unrecorded fires, then the mean individual-tree FI is equal to the population mean FI and the fire rotation. If unrecorded fires were common, then the mean composite FI might better estimate the population mean FI and the fire rotation. However, we argued that the composite FI, unlike the individual-tree FI, is very sensitive to small fires and thus 
Fig. 2. Percentage of the identified fire years versus the number of fire-scarred trees used to document those fire years, based on data from (a) Arno (1976), Onehorse; (b) Arno (1976), Tolan; (c) Arno (1976), West Fork; (d) Dieterich (1980a), Chimney Spring; (e) Dieterich (1980b), Limestone Flats; $(f)$ Stein (1988), Whiteman Spring; $(g)$ Stein (1988), Straight Canyon; $(h)$ Stein (1988), Seiler Mill; ( $i$ ) Rowdabaugh (1978), pre-1840 scars; $(j)$ Brown et al. (1999), Fig. 6; and (k) Goldblum and Veblen (1992) and $(l)$ the mean for the 11 stands. Note that the length of the $X$ axis is scaled to reflect the number of sampled trees.
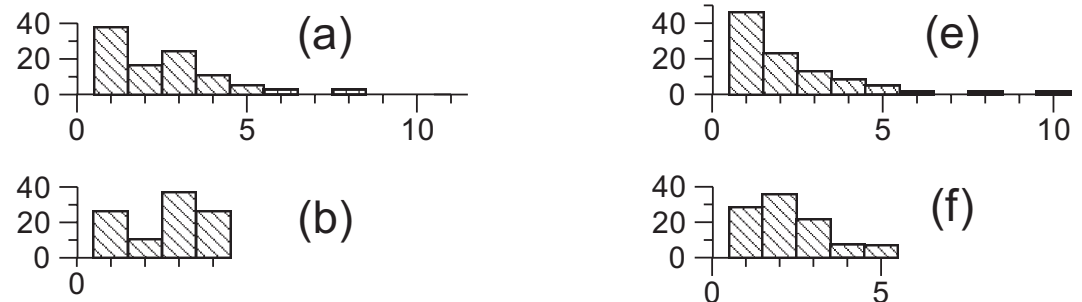

(b)

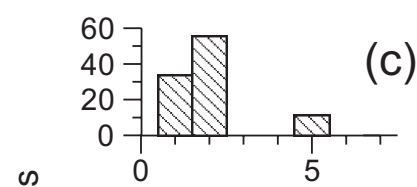

(c)
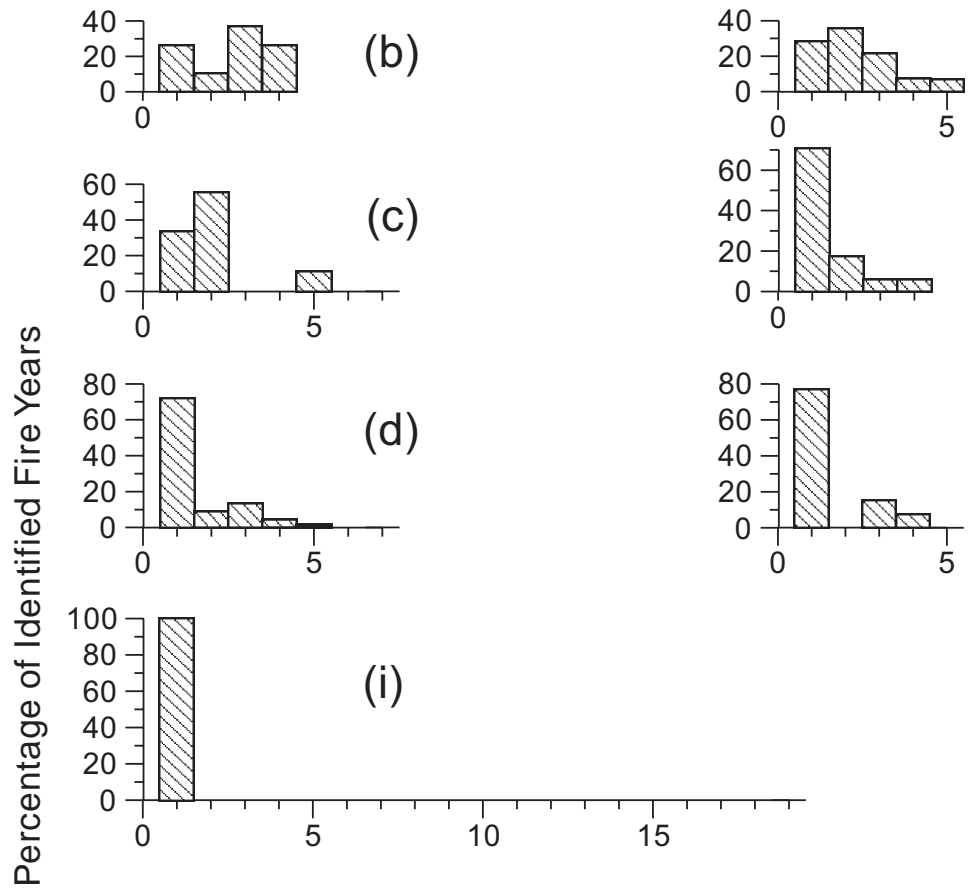

(f)

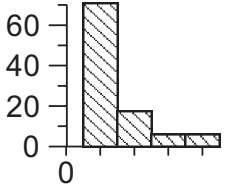

(g)

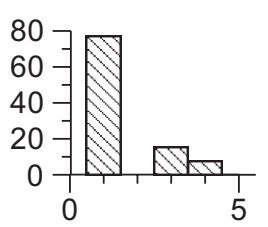

(h)
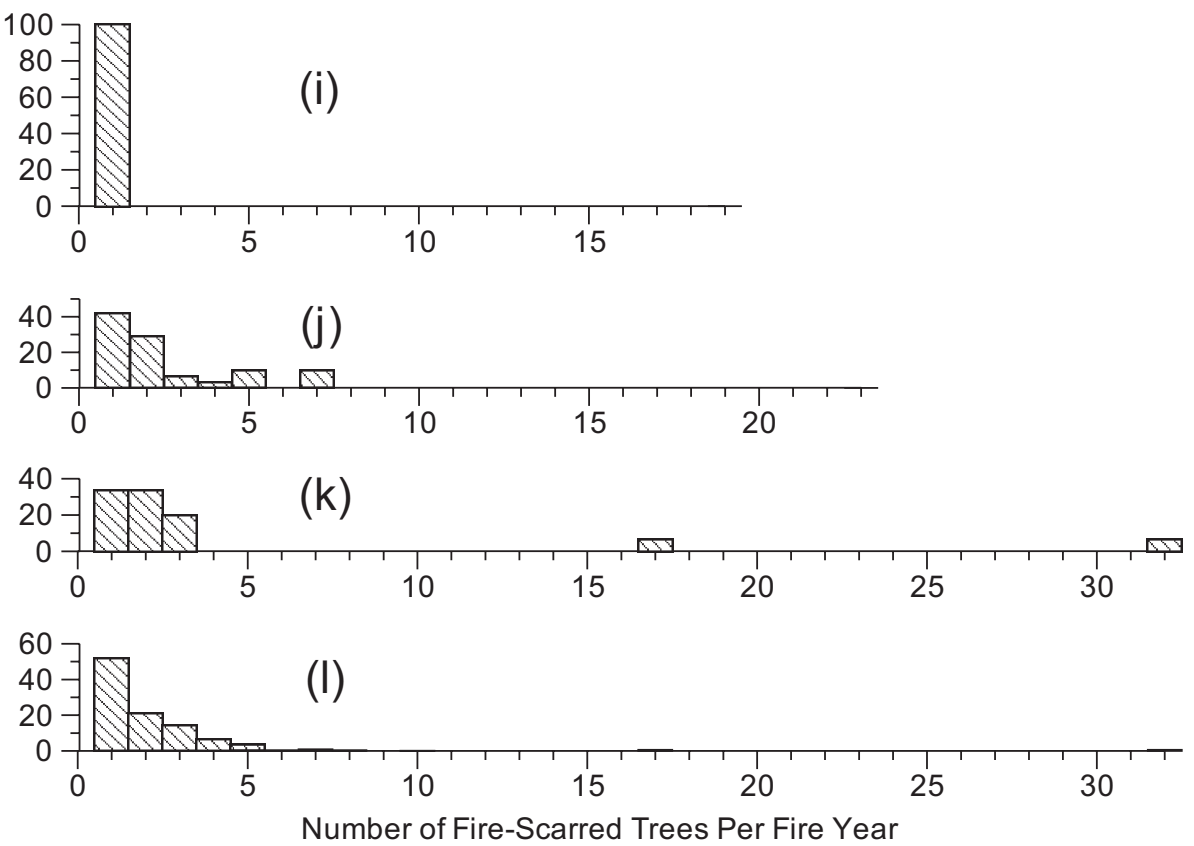

varies with study area size and number of sampled trees. To offset this trend, the restricted composite FI is likely to lead to a better estimate of the population mean FI. How much restriction is needed, however, is unknown, and more research is needed. We suggest that restriction to $>10 \%$ scarred and a minimum of two trees that are not in close proximity may provide an initial restriction that is useful for bracketing, particularly since our review of the effect of restriction suggests the composite FI changes more slowly with greater restriction. Bracketing can also be used with any other parameter (e.g., median, maximum, distribution) of a set of fire intervals.

\section{Fire intervals, tree regeneration, and the origin-to-scar interval in ponderosa pine forests}

Our theoretical arguments suggest some modifications to traditional approaches to analyzing the fire-scar record to explicitly quantify uncertainty. There are other modifications warranted, and other sources of uncertainty, after considering fire intervals in relation to tree regeneration.

Part of the difficulty with linking temporal and spatial components of fire in ponderosa pine forests is that the role of fire in ponderosa pine dynamics remains unclear, but fire 
Table 3. Mortality (percent killed) of seedlings in prescribed and natural (only the Weaver 1947 study) fires in relatively pure ponderosa pine forests of the western United States.

\begin{tabular}{|c|c|c|c|}
\hline Source & Location* & Mortality & Month(s) of burn \\
\hline Gaines et al. 1958 & $\mathrm{EC} \mathrm{AZ}$ & $\begin{array}{l}98-99 \% \text { of seedlings }(<0.3 \mathrm{~m} \text { tall }) \\
\text { most trees }<1.0-1.2 \mathrm{~m} \text { were killed }\end{array}$ & Sept.-Oct. \\
\hline Lindenmuth 1962 & $\mathrm{EC} \mathrm{AZ}$ & $58 \%$ of trees $<1.4 \mathrm{~m}$ tall & Nov.-Dec. \\
\hline Show and Kotok 1924 & $\mathrm{~N} \mathrm{CA}$ & $97 \%$ of trees $<5 \mathrm{~cm} \mathrm{DBH}$ & Spring and fall \\
\hline Gordon 1967 & NE CA & $99 \%$ of understory trees & Oct., May, June \\
\hline Wooldridge and Weaver 1965 & NC WA & $\begin{array}{l}95 \% \text { of trees }<3.0 \mathrm{~m} \text { tall; } \\
98-99 \% \text { of seedlings }(<0.3 \mathrm{~m} \text { tall })\end{array}$ & Sept. \\
\hline Weaver 1947 & NC WA & $\begin{array}{l}90 \% \text { of area of } 40 \text {-year-old } \\
\text { reproduction }\end{array}$ & Sept. \\
\hline Gartner and Thompson 1973 & W SD & Nearly $100 \%$ of seedlings & Apr. \\
\hline Bock and Bock 1984 & W SD & $93 \%$ of trees $<1.4 \mathrm{~m}$ tall & Oct., Apr.-May \\
\hline
\end{tabular}

*AZ, Arizona; CA, California; SD, South Dakota; WA, Washington. EC, east central; N, north; NC, north central; $\mathrm{NE}$, northeast; $\mathrm{W}$, west.

intervals must occur that are sufficiently long to allow some tree regeneration. Fires are thought to both promote regeneration (Show and Kotok 1924; Cooper 1960; Sackett 1984; White 1985) and kill young seedlings (Cooper 1960; Covington and Moore 1992, 1994a, 1994b). The success of tree regeneration may thus be influenced by the net outcome of these competing roles, which must be played out spatially. For ponderosa pine forests to be perpetuated, regeneration must generally occur in fire-free windows that shift spatially across the landscape. Shifting is necessary, as longterm regeneration failure in some part of the landscape may lead to loss of ponderosa pine dominance.

Seedlings in ponderosa pine forests do not scar well, because they have thin bark that offers little resistance to heat, and they are subject to mortality from crown scorch. Also, their stems are of insufficient size to produce the differential heating that leads to leeward scarring as flames pass (Gutsell and Johnson 1996). As a result, in surface fires, seedlings experience mortality rates well above 90\%, although some seedlings do survive (Table 3). Nearly all these studies are of controlled, low-intensity surface fires during modest burning conditions in cool fall or spring periods. Some may argue that higher fuel loads due to fire exclusion may elevate mortality in these controlled burns relative to pre-EuroAmerican conditions. However, this concern is offset by the fact that mortality during hotter periods, when natural fires more likely were common, would also have been higher. One anomalous fire, with $<90 \%$ mortality of seedlings, was during atypical cool conditions in early winter (Lindenmuth 1962). It is well known that as seedlings increase in height and diameter, they have a higher probability of surviving a fire, so high mortality values decrease rapidly as trees reach $5 \mathrm{~cm}$ or more in diameter (citations in Table 3).

The necessary regeneration window may occur primarily when fire fails to reach all locations containing seedlings or when fire occasionally does not reach an intensity sufficient to kill seedlings, essentially the same reasons that a larger tree may lack a scar (Table 1). Surface fires in ponderosa pine forests do generally leave some of the area inside their perimeters unburned (Dieterich 1980a). The unburned area has been found to be $10 \%$ (Wooldridge and Weaver 1965), 14\% (Sackett 1980), 21.5\% (Lindenmuth 1962), 31\% (Show and Kotok 1924), 38\% (Davis 1965), or even 58\% (Gordon
1967) of the area inside the burn perimeter. Many of these fires, however, were low-intensity, cool-season prescribed fires that may be patchier than higher intensity, warm-season fires would be. Sackett et al. (1996) suggest that ponderosa seedlings survive where absence of overstory pines leads to a lack of pine-needle litter sufficient to enable fire spread. Show and Kotok (1924, pp. 60 and 61) also observed the following:

Surface fires during any season of the year, under any method of control, destroy practically all seedling reproduction up to 6 feet high on areas actually burned. Since these fires are normally patchy, however, a single or even a series of light fires does not necessarily result in wiping out completely all small reproduction within the exterior boundaries of the burned area.

Unburned area inside a fire perimeter provides a mechanism for the survival of small groups of trees inside a fire perimeter, but how long must the area remain unburned before seedlings are large enough to be able to survive a fire?

One way to estimate how long the fire-free interval must be for trees to successfully regenerate is to examine the origin-to-scar (OS) interval on fire-scarred trees (Fig. 3). This is the interval between the year of origin of the tree and the occurrence of the first fire scar (Keeley and Stephenson 2000). The logic is that trees that survived fires must generally have experienced the necessary fire-free interval. To evaluate the OS interval, we use available data on its length from five studies that present individual-tree data and three studies with only summary statistics (e.g., mean) (Fig. 3). The first part of Fig. 3, up to about the 41- to 60-year-old age-class, likely reflects the increasing tendency of seedlings to survive a fire, although not without a scar from it. The declining part of the curve, from the 41- to 60-year-old ageclass on to the end, may reflect the increasing ability of the tree, through thicker bark, to resist an initial scar (Vines 1968). It thus appears that, before about 20 years of age (because of death) and after about 150 years of age (because of heat resistance), unscarred trees have a low probability of recording any surface fire. However, these data suggest a firefree interval of about 50 or more years is generally required for ponderosa pine trees to successfully regenerate.

Do the necessary fire-free intervals of 50 or more years commonly occur in ponderosa pine forests? If the composite 
Fig. 3. Percentage of total scarred trees receiving their first fire scar after particular time intervals. These time intervals also represent the origin-to-scar (OS) interval for the tree.

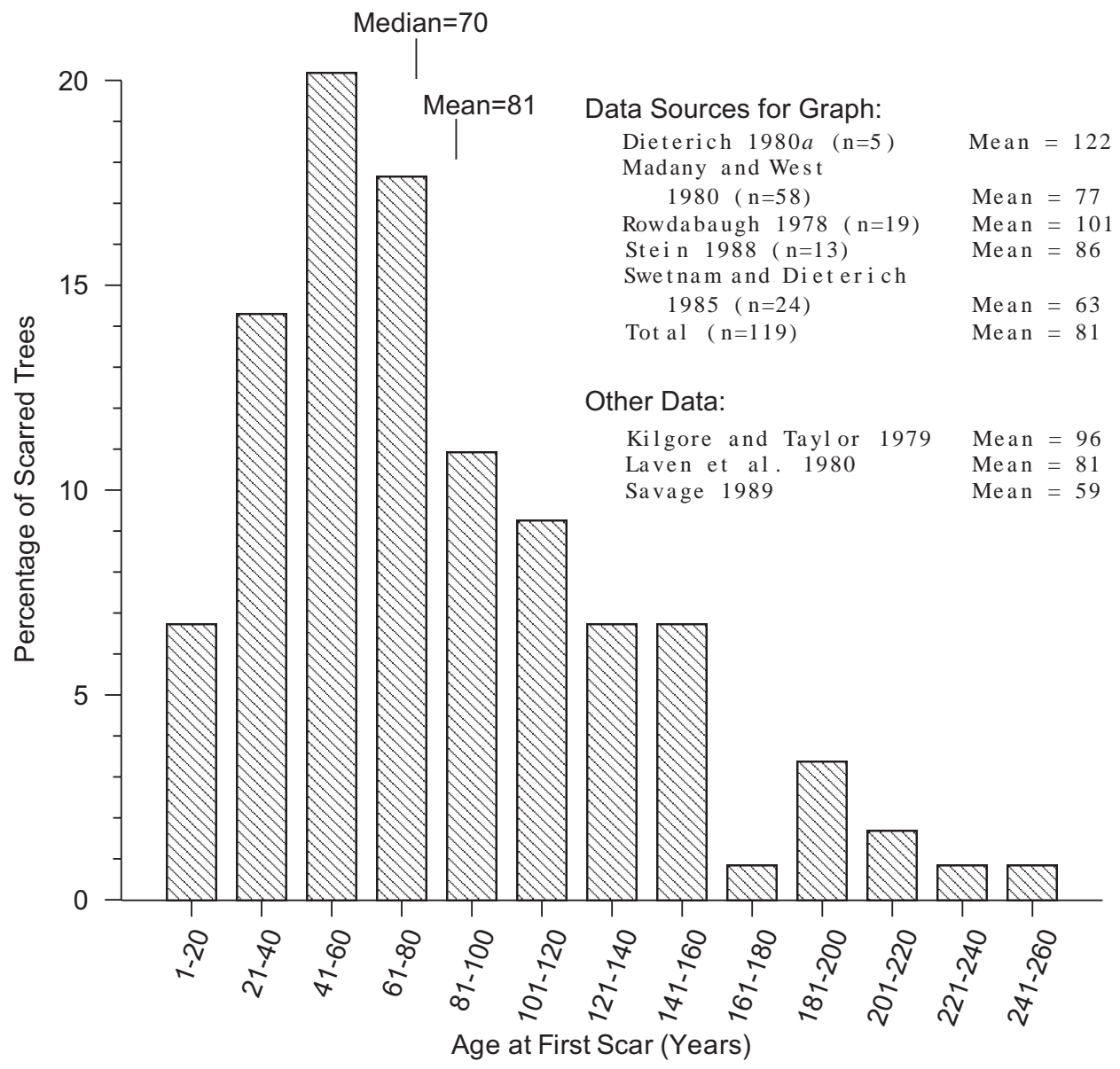

FIs, under the maximum fire assumption, mean that fires recurred every 2-25 years at a point (Fig. $4 a$, Table 4 ), regeneration could not generally succeed. However, the maximum interval, not the mean FI, may be most relevant. In only a few stands do maximum composite FIs occasionally reach the necessary 50 or more years (Fig. 4b). Such long intervals are almost non-existent in the southwestern United States (Table 4; see ranges from studies in New Mexico and Arizona), where composite FIs are generally shortest. Under the equivocal fire interpretation, reported mean composite FIs (Fig. 4a, Table 4) imply only that a fire occurred somewhere in the study area about every 2-25 years. There would always be places that experienced longer fire intervals, and it is in these places that fire intervals sufficient for tree regeneration must have occurred. The mean OS interval of 81 years is also within the range of individual-tree FIs in many stands where data are available (Table 4; see individual-tree FI ranges). This comparison suggests that the necessary firefree intervals of 50 or more years did occur in ponderosa pine stands.

Since the interval needed for tree regeneration must occur in these stands, this interval should be included in the estimate of the population mean FI. There are a few considerations when using the OS as a fire interval. First, it is not clear that it always begins with a fire, since tree regeneration in ponderosa pine forests can be initiated by a variety of events and conditions, such as favorable climatic episodes
(Savage et al. 1996). Second, there are dating problems. The fire scars from which a pith date comes may have been obtained some distance above the root collar, so the pith date is not as early as the actual birth date of the tree. However, these problems both would mean that the population OS interval may actually be longer than the estimated OS interval. Better estimates of the OS interval and more complete firescar records in general can be obtained from wedges or core samples extracted closer to the tree base (Dieterich and Swetnam 1984). If this is not possible, an estimate of potential dating errors can be added to the OS interval, as is commonly done in estimating the origin date of trees. Since the population fire-free interval may be at least as long as the OS interval, the OS interval is still appropriate to include when bracketing. Omitting it is also an error, possibly a larger one, since it estimates a real fire interval, and is often among the longest and most ancient intervals in the record. Finally, just as with any fire interval, there is potential for unrecorded fires. Seedlings are less likely than are larger trees to survive unrecorded fires, so the OS interval is more likely than scar-to-scar intervals to be a true fire-free interval.

What is the effect of including the OS interval in the calculation of mean FIs? We compared mean individual-tree FI without and with the OS interval for eight stands where necessary data were available (Table 5). Mean individual-tree FI with OS is strongly linearly related to mean individual-tree 
Fig. 4. Stand-level (a) mean composite fire intervals and $(b)$ maximum composite fire intervals in ponderosa pine forests of the western United States, for two levels of sampling intensity. The studies that are the basis for this graph are listed in Table 4.
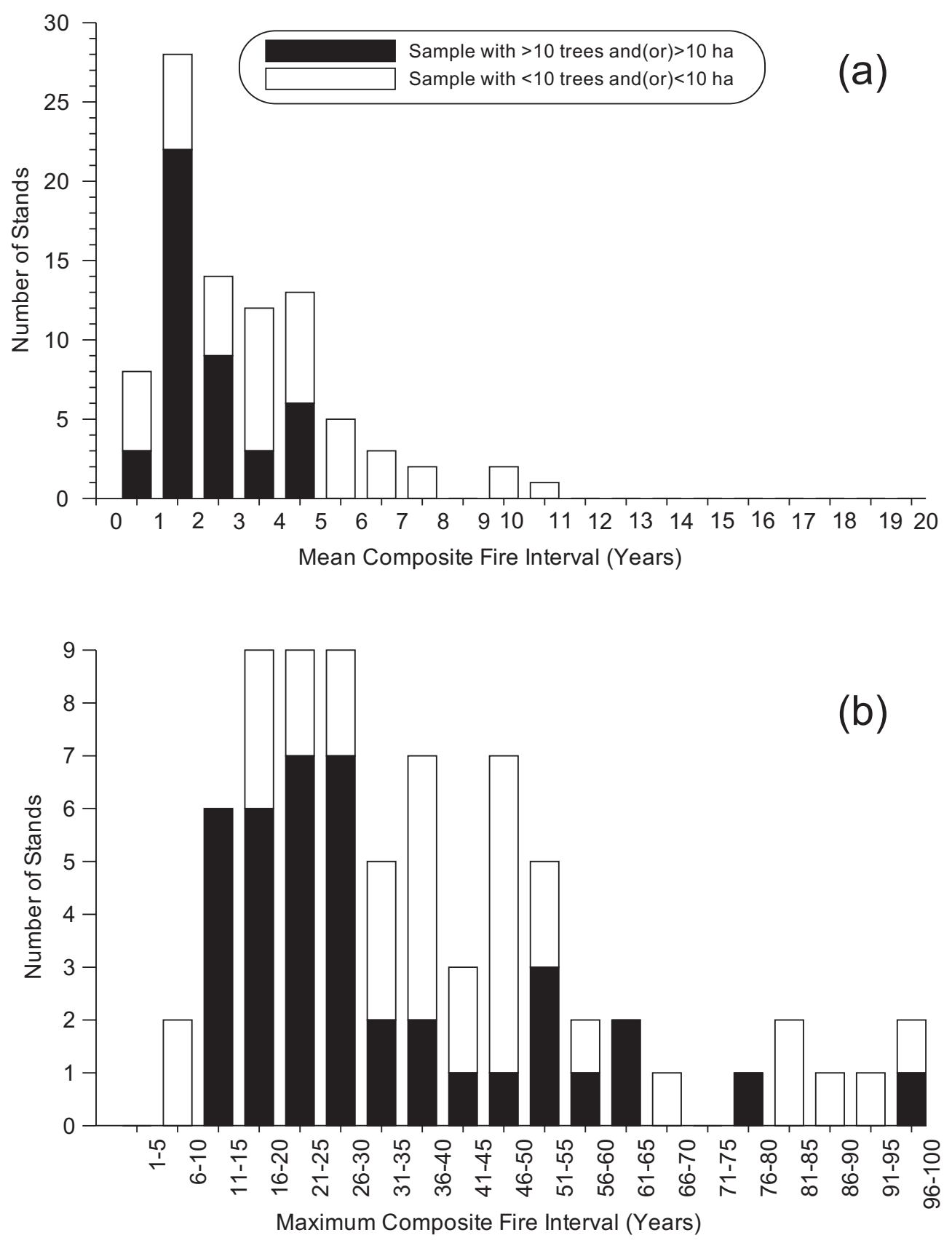

FI without OS, and is, on average, about 1.6 times mean individual-tree FI without OS (Table 5, Fig. 5). This estimate is based on a small sample, and the OS values are potentially imprecise because of dating problems. Our purpose, however, is to provide an initial estimate of the magnitude of the effect from omitting the OS and to encourage collection and use of OS data.

\section{Potential biases in sampling methods in fire-history analysis}

\section{Sample size}

Since a restricted mean composite FI is one potential limit for the bracketed estimate of the population mean FI, it is important to evaluate the mean composite FI further. Since small fires may be common, we expected area sampled and number of sampled trees to influence variation in available estimates of mean composite FI throughout the western United States (Fig. 6, Table 4). This relationship has been found previously in smaller areas (e.g., Arno and Petersen 1983). We divided the part of the western United States, for which stand-level data are available, into three regions (Fig. 6). We then used MINITAB version 12 (MINITAB, Inc. 1997) to complete a best subset regression (Draper and Smith 1981), with region as a dummy variable and with stand area and number of sampled trees as possible predictors of mean composite FI. Overall, region is the strongest predictor of mean composite FI $\left(R_{\mathrm{adj}}^{2}=29.9 \%\right)$, but stand 
Table 4. Studies of fire history in ponderosa pine forests of the western United States.

\begin{tabular}{|c|c|c|c|c|c|c|c|c|c|c|c|c|}
\hline \multirow[b]{2}{*}{ Source } & \multicolumn{5}{|l|}{ Sites } & \multicolumn{3}{|l|}{ Stands } & \multicolumn{2}{|c|}{ Stand composite FI } & \multicolumn{2}{|c|}{$\begin{array}{l}\text { Stand individual- } \\
\text { tree FI }\end{array}$} \\
\hline & Location $^{a}$ & $\begin{array}{l}\text { Area or } \\
\text { extent of } \\
\text { site }\end{array}$ & $\begin{array}{l}\text { No. of } \\
\text { trees }\end{array}$ & $\begin{array}{l}\text { Mean } \\
\text { (years) }\end{array}$ & $\begin{array}{l}\text { Range } \\
\text { (years) }\end{array}$ & Stand No. or name & $\begin{array}{l}\text { Stand area } \\
\text { (ha) }\end{array}$ & $\begin{array}{l}\text { No. of } \\
\text { trees }\end{array}$ & $\begin{array}{l}\text { Mean } \\
\text { (years) }\end{array}$ & $\begin{array}{l}\text { Range } \\
\text { (years) }\end{array}$ & $\begin{array}{l}\text { Mean } \\
\text { (years) }\end{array}$ & $\begin{array}{l}\text { Range } \\
\text { (years) }\end{array}$ \\
\hline \multirow{3}{*}{$\begin{array}{l}\text { Arno 1976; } \\
\text { Arno and Petersen } 1983\end{array}$} & \multirow[t]{3}{*}{ W MT } & \multirow{3}{*}{$\begin{array}{l}\text { Within } \\
100 \mathrm{~km}\end{array}$} & \multirow[t]{3}{*}{-} & \multirow[t]{3}{*}{-} & \multirow[t]{3}{*}{ - } & Onehorse & $80-325$ & 11 & 6 & $2-20$ & 23 & - \\
\hline & & & & & & Tolan & $80-325$ & 4 & 11 & $2-18$ & 11 & - \\
\hline & & & & & & West Fork & $80-325$ & 7 & 10 & $2-18$ & 21 & - \\
\hline \multirow{9}{*}{ Arno et al. 1995} & \multirow[t]{9}{*}{ W MT } & \multirow{3}{*}{$\begin{array}{l}\text { Within } \\
15 \mathrm{~km}\end{array}$} & \multirow{3}{*}{ - } & \multirow{3}{*}{ - } & \multirow{3}{*}{ - } & $1-1$ & 1 & $2-4$ & 32 & $17-47$ & - & - \\
\hline & & & & & & $1-2$ & 1 & $2-4$ & 31 & $17-47$ & - & - \\
\hline & & & & & & $1-3$ & 1 & $2-4$ & 26 & $7-51$ & - & - \\
\hline & & \multirow{3}{*}{$\begin{array}{l}\text { Within } \\
0.5 \mathrm{~km}\end{array}$} & \multirow[t]{4}{*}{-} & \multirow[t]{4}{*}{ - } & \multirow[t]{4}{*}{ - } & $2-1$ & 1 & $2-4$ & 47 & $19-83$ & - & - \\
\hline & & & & & & $2-2$ & 1 & $2-4$ & 52 & $37-85$ & - & - \\
\hline & & & & & & $2-3$ & 1 & $2-4$ & 50 & $35-97$ & - & - \\
\hline & & - & & & & $3-1$ & 1 & $2-4$ & 13 & $5-41$ & - & - \\
\hline & & Within & - & - & - & $4-1$ & 1 & $2-4$ & 31 & $8-66$ & - & - \\
\hline & & $5 \mathrm{~km}$ & & & & $4-2$ & 1 & $2-4$ & 18 & $11-28$ & - & - \\
\hline Barrett 1988 & NE ID & 1215 ha & 75 & 4 & - & 10 stands & $<40$ & ca. 2 each & $10-18$ & $5-28$ & - & - \\
\hline Bork 1984 & $\mathrm{C} \mathrm{OR}$ & Unknown & 31 & 7 & - & 6 stands & 16 & ca. 5 each & 24 & $16-38$ & - & $4-100$ \\
\hline & & & 35 & 4 & - & 6 stands & 16 & ca. 6 each & 11 & $7-20$ & - & $13-74$ \\
\hline & & & 48 & 8 & - & 6 stands & 16 & ca. 8 each & 15 & $9-25$ & - & $13-100$ \\
\hline Brown et al. 1999 & $\mathrm{C} \mathrm{CO}$ & 3000 ha & 153 & 9 & $1-29$ & Old cluster & 30 & 23 & 21 & $3-58$ & $77^{b}$ & $3-160^{b}$ \\
\hline Brown et al. 2000 & W SD & Within & 19 & - & - & UPC & $10-20$ & 9 & - & $11-74$ & - & - \\
\hline & & $0.5 \mathrm{~km}$ & & & & UPM & $10-20$ & 10 & - & $13-72$ & - & - \\
\hline & SE WY & Within & 22 & - & - & ASL & $10-20$ & 12 & - & $8-74$ & - & - \\
\hline & & $1 \mathrm{~km}$ & & & & ASU & $10-20$ & 10 & - & $8-82$ & - & - \\
\hline & $\mathrm{S} \mathrm{CO}$ & $10-20$ ha & 17 & - & - & HCK & $10-20$ & 17 & - & $2-41$ & - & - \\
\hline Brown and Sieg 1996 & W SD & Within & 57 & 16 & $1-45$ & JCS & ca. 50 & 16 & 23 & $7-93$ & $32^{c}$ & $7-195^{c}$ \\
\hline & & $7 \mathrm{~km}$ & & & & JCE & ca. 200 & 16 & 23 & $1-77$ & $37^{c}$ & $5-157^{c}$ \\
\hline & & & & & & $\mathrm{JCN}$ & ca. 50 & 11 & 20 & $4-45$ & $31^{c}$ & $6-88^{c}$ \\
\hline & & & & & & $\mathrm{JCC}$ & ca. 50 & 14 & 23 & $1-63$ & $42^{c}$ & $5-154^{c}$ \\
\hline Brown and Sieg 1999 & W SD & Within & 42 & - & - & WCN & $20-25$ & 12 & 12 & $3-32$ & - & - \\
\hline & & $12 \mathrm{~km}$ & & & & PIG & $20-25$ & 14 & 10 & $2-23$ & - & - \\
\hline & & & & & & GOB & $20-25$ & 16 & 12 & $3-34$ & - & - \\
\hline Dieterich $1980 a$ & N AZ & Unknown & - & - & - & Chimney Spring & $<10$ & 7 & $5^{d}$ & $1-31$ & $11^{c}$ & $2-31^{c}$ \\
\hline Dieterich $1980 b$ & N AZ & Unknown & - & - & - & Limestone Flats & $<10$ & 10 & 2 & $1-9$ & - & - \\
\hline Dieterich and Hibbert 1990 & $\mathrm{~N}$ AZ & Unknown & - & - & - & Battle Flat & 87 & 7 & 2 & - & - & - \\
\hline Freedman and Habeck & NW MT & Within & Unknown & 14 & $\sim 2-88$ & 21 & 0.0375 & Unknown & 22 & $\sim 2-88^{b}$ & - & - \\
\hline 1985 & & $30 \mathrm{~km}$ & & & & 23 & 0.0375 & Unknown & 25 & $8-40$ & - & - \\
\hline & & & & & & 27 & 0.0375 & Unknown & 24 & $\sim 5-49^{b}$ & - & - \\
\hline & & & & & & 29 & 0.0375 & Unknown & 30 & $\sim 10-58^{b}$ & - & - \\
\hline & & & & & & 31 & 0.0375 & Unknown & 26 & $\sim 3-54^{b}$ & - & - \\
\hline & & & & & & 35 & 0.0375 & Unknown & 23 & $\sim 9-37^{b}$ & - & - \\
\hline & & & & & & 36 & 0.0375 & Unknown & 16 & $\sim 5-30^{b}$ & - & - \\
\hline & & & & & & 40 & 0.0375 & Unknown & 26 & $17-38$ & - & - \\
\hline & & & & & & 44 & 0.0375 & Unknown & 36 & $20-48^{b}$ & - & - \\
\hline & & & & & & 48 & 0.0375 & Unknown & 25 & $9-40$ & - & - \\
\hline
\end{tabular}


Fulé et al. 1997

and Veblen 1992

Grissino-Mayer 1995

\section{$\mathrm{N} \mathrm{CO}$}

700 ha

Within ca.

$20 \mathrm{~km}$
Heyerdahl 1997

Laven et al. 1980

Madany and West 1980
NE OR

$\mathrm{N} \mathrm{CO}$

SW UT ca. 1620 ha ca. 1620 ha ca. 1620 ha ca. 1620 ha 3640 ha $\quad-$
$4 \quad 2-8 \quad-$

- $\quad-\quad-$

Cerro Bandera N

La Marchanita

Candelaria

Hoya de Cibola

Mesita Blanca

Hidden Kipuka

2 stands

2 stands

1 stand

8 stands

Wintersteen Park

2
3
4
5

$\begin{array}{lll}4 & 0.5-2.0 & 3 \\ 5 & 0.5-2.0 & 3 \\ 7 & 0.5-2.0 & 4 \\ 8 & 0.5-2.0 & 2 \\ 9 & 0.5-2.0 & 2 \\ 10 & 0.5-2.0 & 3 \\ 11 & 0.5-2.0 & 4 \\ 12 & 0.5-2.0 & 2 \\ 13 & 0.5-2.0 & 2 \\ \text { None } & 0.5-2.0 & 5 \\ \text { None } & - & - \\ \text { Snag Saddle } & - & - \\ \text { Side Canyon 3 } & 10-100 & 4 \\ \text { Ledge } & 10-100 & 7 \\ \text { None } & 10-100 & 7 \\ \text { None } & - & - \\ & - & - \\ \text { None } & & \\ - & - & - \\ \text { Moraine Park } & \text { Unknown } & 2 \\ \text { Beaver Mead. } & \text { Unknown } & 3 \\ \text { Horseshoe Park } & \text { Unknown } & 1 \\ \text { Hondius Park } & \text { Unknown } & 2 \\ \text { None } & - & - \\ \text { None } & - & - \\ \text { None } & - & - \\ 5 & <10 & 1-3 \\ \text { Whiteman Spring } & \text { Unknown } & 5 \\ & & \\ & & \end{array}$

\begin{tabular}{|c|c|c|c|}
\hline- & - & - & - \\
\hline $16^{d}$ & $2-49$ & 69 & $27-173$ \\
\hline 6 & $1-12$ & - & - \\
\hline 9 & $1-25$ & - & - \\
\hline 8 & $2-28$ & - & - \\
\hline 6 & $1-16$ & - & - \\
\hline 6 & $1-16$ & - & - \\
\hline 7 & $2-17$ & - & - \\
\hline 12 & $2-31$ & - & - \\
\hline 9 & $2-29$ & - & - \\
\hline 14 & $3-55$ & - & - \\
\hline $27,71^{c}$ & - & - & - \\
\hline $24,107^{c}$ & - & - & - \\
\hline $13^{c}$ & - & - & - \\
\hline median 12 & - & - & - \\
\hline- & - & 66 & $5-157$ \\
\hline $28^{c}$ & - & - & - \\
\hline $22^{c}$ & - & - & - \\
\hline $19^{c}$ & - & - & - \\
\hline $37^{c}$ & - & - & - \\
\hline $14^{c}$ & - & - & - \\
\hline $14^{c}$ & - & - & - \\
\hline $19^{c}$ & - & - & - \\
\hline $19^{c}$ & - & - & - \\
\hline $9^{c}$ & - & - & - \\
\hline $22^{c}$ & - & - & - \\
\hline $16^{c}$ & - & - & - \\
\hline $19^{c}$ & - & - & - \\
\hline $7^{c}$ & - & - & - \\
\hline- & - & - & - \\
\hline - & - & - & - \\
\hline 5 & $1-9$ & - & - \\
\hline 8 & $1-29$ & - & - \\
\hline 10 & $1-27$ & - & - \\
\hline - & - & - & - \\
\hline - & - & - & - \\
\hline - & - & - & - \\
\hline - & - & $49^{c}$ & $24-76$ \\
\hline - & - & 58 & $50-65$ \\
\hline - & - & $62^{c}$ & $55-76^{c}$ \\
\hline - & - & 34 & - \\
\hline - & - & 28 & 24-32 \\
\hline- & - & - & - \\
\hline - & - & - & - \\
\hline & - & - & - \\
\hline ca. $22^{b}$ & - & - & - \\
\hline 16 & $4-35^{c}$ & $23^{c}$ & $12-41$ \\
\hline
\end{tabular}

McBride and Jacobs 1980

McBride and Laven 1976

Morino 1996

Rowdabaugh 1978

Savage 1989; Savage and Swetnam 1990

Sherman 1969

Skinner and Laven 1982

\section{S CA}

S CA

$\mathrm{N} \mathrm{CO}$ NW NM

C OR

$\mathrm{N} \mathrm{CO}$

E OR

W ID Steele et al. 1986 Stein 1988 ca. 3000 ha 75 ca. 8000 ha 123 ca. 6000 ha 64 78400 ha -

\begin{tabular}{|c|c|c|c|c|}
\hline \\
\hline Unknown & - & 10 & - & None \\
\hline Unknown & 26 & 10 & - & None \\
\hline Unknown & - & - & - & $\begin{array}{l}\text { Snag Saddle } \\
\text { Side Canyon } 3 \\
\text { Ledge }\end{array}$ \\
\hline Unknown & 19 & $10^{c}$ & $1-56^{c}$ & None \\
\hline 6563 ha & 16 & 3 & $1-18$ & None \\
\hline ca. 2000 ha & 85 & 12 & - & None \\
\hline Unknown & 8 & - & - & - \\
\hline & & & & $\begin{array}{l}\text { Moraine Park } \\
\text { Beaver Mead. } \\
\text { Horseshoe Park } \\
\text { Hondius Park }\end{array}$ \\
\hline ca. 3000 ha & 75 & - & - & None \\
\hline ca. 8000 ha & 123 & - & - & None \\
\hline ca. 6000 ha & 64 & - & - & None \\
\hline Unknown & - & - & - & 5 \\
\hline 78400 ha & - & - & - & Whiteman Spring \\
\hline
\end{tabular}

\begin{tabular}{|c|c|}
\hline - & - \\
\hline 600 & 67 \\
\hline 12.3 & 32 \\
\hline 8.2 & 11 \\
\hline 10.6 & 20 \\
\hline 14.0 & 35 \\
\hline 42.9 & 37 \\
\hline 8.5 & 20 \\
\hline 12.6 & 23 \\
\hline 54.8 & 26 \\
\hline 28.9 & 13 \\
\hline 1 & $1-8$ \\
\hline 1 & $1-8$ \\
\hline 1 & $1-8$ \\
\hline 1 & $1-8$ \\
\hline 50 & 20 \\
\hline $0.5-2.0$ & 4 \\
\hline $0.5-2.0$ & 2 \\
\hline $0.5-2.0$ & 2 \\
\hline $0.5-2.0$ & 3 \\
\hline $0.5-2.0$ & 3 \\
\hline $0.5-2.0$ & 4 \\
\hline $0.5-2.0$ & 2 \\
\hline $0.5-2.0$ & 2 \\
\hline $0.5-2.0$ & 3 \\
\hline $0.5-2.0$ & 4 \\
\hline $0.5-2.0$ & 2 \\
\hline $0.5-2.0$ & 2 \\
\hline $0.5-2.0$ & 5 \\
\hline- & - \\
\hline - & - \\
\hline $10-100$ & 4 \\
\hline 10-100 & 7 \\
\hline $10-100$ & 7 \\
\hline - & - \\
\hline - & - \\
\hline - & - \\
\hline - & 一 \\
\hline Unknown & 2 \\
\hline Unknown & 3 \\
\hline Unknown & 1 \\
\hline Unknown & 2 \\
\hline - & - \\
\hline - & - \\
\hline - & - \\
\hline$<10$ & $1-3$ \\
\hline Unknown & 5 \\
\hline
\end{tabular}

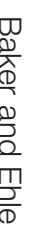




\begin{tabular}{|c|c|c|c|c|c|c|c|c|c|c|c|c|}
\hline \multirow[b]{2}{*}{ Source } & \multicolumn{5}{|l|}{ Sites } & \multicolumn{3}{|l|}{ Stands } & \multicolumn{2}{|c|}{ Stand composite FI } & \multicolumn{2}{|c|}{$\begin{array}{l}\text { Stand individual- } \\
\text { tree FI }\end{array}$} \\
\hline & Location $^{a}$ & $\begin{array}{l}\text { Area or } \\
\text { extent of } \\
\text { site }\end{array}$ & $\begin{array}{l}\text { No. of } \\
\text { trees }\end{array}$ & $\begin{array}{l}\text { Mean } \\
\text { (years) }\end{array}$ & $\begin{array}{l}\text { Range } \\
\text { (years) }\end{array}$ & Stand No. or name & $\begin{array}{l}\text { Stand area } \\
\text { (ha) }\end{array}$ & $\begin{array}{l}\text { No. of } \\
\text { trees }\end{array}$ & $\begin{array}{l}\text { Mean } \\
\text { (years) }\end{array}$ & $\begin{array}{l}\text { Range } \\
\text { (years) }\end{array}$ & $\begin{array}{l}\text { Mean } \\
\text { (years) }\end{array}$ & $\begin{array}{l}\text { Range } \\
\text { (years) }\end{array}$ \\
\hline \multirow{13}{*}{ Swetnam and Baisan $1996 a$} & \multirow{13}{*}{$\mathrm{AZ}$ and $\mathrm{NM}$} & \multirow{13}{*}{ Unknown } & \multirow{13}{*}{ - } & \multirow{13}{*}{ - } & \multirow{13}{*}{-} & Straight Canyon & Unknown & 4 & 15 & $2-43^{c}$ & $30^{c}$ & $9-59$ \\
\hline & & & & & & Seiler Mill & Unknown & 5 & 18 & $1-48^{c}$ & $32^{c}$ & $11-81$ \\
\hline & & & & & & Camp May East & $10-100$ & 6 & 17 & $1-46$ & - & - \\
\hline & & & & & & Canada Bonita S & $10-100$ & 31 & 10 & $2-29$ & - & - \\
\hline & & & & & & Capulin C. Mid. & $10-100$ & 15 & 9 & $1-21$ & - & - \\
\hline & & & & & & Rito de los Fri. 3 & $10-100$ & 18 & 6 & $1-13$ & - & - \\
\hline & & & & & & Rito de los Fri. 5 & $10-100$ & 12 & 8 & $1-24$ & - & - \\
\hline & & & & & & Manzano Mountains N & $10-100$ & 19 & 9 & $2-38$ & - & - \\
\hline & & & & & & Castle Creek & $10-100$ & 17 & 3 & $1-11$ & - & - \\
\hline & & & & & & Fillmore Creek 1 & $10-100$ & 7 & 5 & $1-21$ & - & - \\
\hline & & & & & & Fillmore Creek 3 & $10-100$ & 10 & 6 & $1-23$ & - & - \\
\hline & & & & & & Ice Canyon & $10-100$ & 7 & 7 & $1-33$ & - & - \\
\hline & & & & & & Zuni Mountains & $10-100$ & 7 & 6 & $1-17$ & - & - \\
\hline \multirow[t]{2}{*}{ Swetnam and Baisan $1996 b$} & \multirow[t]{2}{*}{ SE AZ } & \multirow[t]{2}{*}{ Unknown } & \multirow[t]{2}{*}{ - } & \multirow[t]{2}{*}{-} & \multirow[t]{2}{*}{ - } & Rose Canyon & Unknown & 11 & 6 & $1-15$ & - & - \\
\hline & & & & & & Animas North & Unknown & 18 & 5 & $1-16$ & - & - \\
\hline \multirow{3}{*}{$\begin{array}{l}\text { Swetnam and Dieterich } \\
1985\end{array}$} & \multirow[t]{3}{*}{ SW NM } & \multirow[t]{3}{*}{303500 ha } & \multirow[t]{3}{*}{ - } & \multirow[t]{3}{*}{ - } & \multirow[t]{3}{*}{ - } & McKenna Park & $<160$ & 16 & $5^{c}$ & $1-16$ & $14^{c}$ & $3-130^{c}$ \\
\hline & & & & & & Langstroth Mesa & $<160$ & 18 & $5^{c}$ & $1-26$ & $12^{c}$ & $2-147^{c}$ \\
\hline & & & & & & Gilita Ridge & $<40$ & 10 & $8^{c}$ & $1-39$ & $16^{c}$ & $1-66^{c}$ \\
\hline \multirow[t]{2}{*}{ Touchan et al. 1995} & \multirow[t]{2}{*}{ N NM } & \multirow[t]{2}{*}{ Unknown } & - & - & - & Monument Canyon & 259 & 30 & 6 & $1-12$ & - & - \\
\hline & & & & & & Continental Divide & 27 & 27 & 12 & $1-12$ & - & - \\
\hline Touchan et al. 1996 & N NM & Unknown & - & - & - & Ban-Group 3 & 110 & 18 & 6 & $1-21$ & - & - \\
\hline & & & & & & Pajarito Mtn. Ridge & 3.5 & 26 & 6 & $1-21$ & - & - \\
\hline & & & & & & C. Pedernal & 16 & 26 & 12 & $1-51$ & - & - \\
\hline & & & & & & Clear Creek C.G. & 130 & 20 & 6 & $1-24$ & - & - \\
\hline Veblen et al. 1996 & $\mathrm{~N} \mathrm{CO}$ & Within & - & - & - & LSB & 123 & 55 & 7 & $1-29$ & 30 & $3-84$ \\
\hline & & $40 \mathrm{~km}$ & & & & MSB & 291 & 71 & 12 & $1-54$ & 73 & $9-87$ \\
\hline & & & & & & LMB & 281 & 70 & 8 & $1-65$ & 43 & $4-72$ \\
\hline & & & & & & FMI & 172 & 59 & 11 & $1-39$ & 46 & $4-118$ \\
\hline & & & & & & ULH & 267 & 76 & 13 & $1-100$ & 73 & $7-130$ \\
\hline & & & & & & JCR & 219 & 43 & 21 & $1-49$ & 53 & $12-73$ \\
\hline & & & & & & SSV & 597 & 98 & 9 & $1-30$ & 46 & 9-109 \\
\hline & & & & & & NSV & 384 & 45 & 12 & $1-33$ & 62 & $23-85$ \\
\hline
\end{tabular}

Note: Studies are included if they are published or generally available; excluded are unpublished reports. Where the cited studies contained data from forests other than relatively pure ponderosa pine,

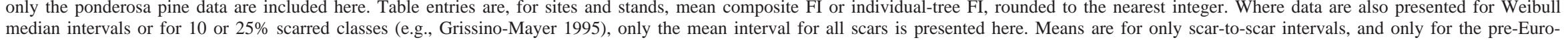
American period, where it was possible to separate data by period. Some studies present data at other spatial scales (e.g., watershed; Madany and West 1980), but these other scales are omitted here. Some studies (e.g., Fisher et al. 1987) are not included here, because they do not report intervals for all fires or contain little or no record of pre-Euro-American fires (e.g., Weaver 1951) or are based on isolated, single trees (Weaver 1951, 1959). Some studies repeat data from previous studies; only new sites are included. Number of trees is the number of fire-scarred trees sampled.

${ }^{a}$ AZ, Arizona; CA, California; CO, Colorado; ID, Idaho; NM, New Mexico; OR, Oregon; SD, South Dakota; UT, Utah; WA, Washington; WY, Wyoming. C, Central; E, east; EC, east central; N, north; NE, northeast; NW, northwest; S, south; SE, southeast; SW, southwest; W, west.

${ }^{b}$ Value has been estimated from a graph.

${ }^{c}$ Value has been computed from data in a table or graph

${ }^{d}$ Value has been re-computed, because number of fires rather than number of intervals was used to calculate the mean interval. 
Table 5. Comparison of mean individual-tree FI without and with the origin-to-scar (OS) interval included, for eight stands of ponderosa pine.

\begin{tabular}{llllll}
\hline & & & \multicolumn{3}{l}{ Mean individual-tree FI } \\
\cline { 5 - 6 } Source & Location & Stand name & Without OS & With OS & Ratio \\
\hline Dieterich 1980a & NC AZ & Chimney Spring & 12.0 & 24.0 & 2.00 \\
Rowdabaugh 1978 & NE CO & - & 39.8 & 69.9 & 1.76 \\
Stein 1988 & SW UT & Whiteman Spring & 22.9 & 35.9 & 1.57 \\
Stein 1988 & SW UT & Straight Canyon & 27.3 & 45.7 & 1.67 \\
Stein 1988 & SW UT & Seiler Mill & 32 & 43.1 & 1.35 \\
Swetnam and Dieterich 1985 & SW NM & McKenna Park & 13 & 16.6 & 1.28 \\
Swetnam and Dieterich 1985 & SW NM & Langstroth Mesa & 12 & 19.7 & 1.64 \\
Swetnam and Dieterich 1985 & SW NM & Gilita Ridge & 15.1 & 20.6 & 1.36 \\
Mean & & & 21.8 & 34.4 & 1.58 \\
\hline
\end{tabular}

Note: These stands are the only eight for which appropriate data (years for each fire and pith year) are available. Means reported here may differ from those in Table 4, because only trees that contained the pith could be used here. See Table 4 for location abbreviations.

Fig. 5. The relationship of mean individual-tree FI with the origin-to-scar (OS) interval included and without the OS interval included. The line is the result of a linear regression using MINITAB (MINITAB, Inc. 1997).

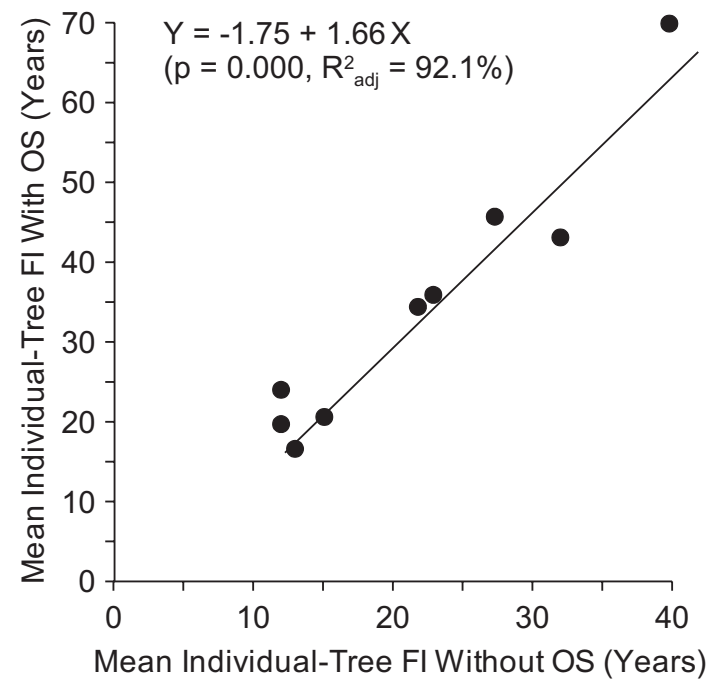

area accounts for an additional $13.1 \%\left(R_{\mathrm{adj}}^{2}\right)$ of the variation in mean composite FI. Within the northern Rockies, stand area accounts for $38.4 \%\left(R_{\mathrm{adj}}^{2}\right)$ of the variation in mean composite FI. In the southern Rockies, number of sampled trees accounts for $66.8 \%\left(R_{\text {adj }}^{2}\right)$ of the variation in mean composite FI. In the Southwest, number of sampled trees $\left(R_{\mathrm{adj}}^{2}=\right.$ $18.5 \%)$ and stand area $\left(R_{\text {adj }}^{2}=6.9 \%\right)$ explain less of the variation in mean composite FI. Sampling intensity (area, number of trees) is thus potentially important in explaining variation in mean post-CIs within some parts of the western United States.

A brief aside is in order. Here and in other places in this paper we use parametric statistics. Fire-interval data within a stand are often not normally distributed (Grissino-Mayer 2000), suggesting that nonparametric statistics may be appropriate. However, mean FIs, compared among stands, appear to have distributions that are unimodal and not strongly skewed, once inadequately sampled stands are omitted (solid bars in Fig. 4a). Thus, parametric statistics may be appropri- ate when comparing stand-level summary data among sites. Further analysis of fire-interval data and appropriate statistical techniques is warranted.

If sample size influences composite FI, is there a minimum sample size needed for estimating stand-level composite FI? We could best test this by re-calculating mean composite FI as sampling area and number of trees increase, but insufficient data are available for this in the published literature (Table 4). We instead used the number of detected fires, which is directly related to mean composite FI; all studies with sufficient data were included (Table 4). Where the final number of detected fires is less than about 20 for a particular stand, new fires accumulate more slowly after about 10 fire-scarred trees or even fewer in some instances (Fig. 7). Where the number of detected fires is greater than about 20, a decline in accumulation seems to occur after more than about 10 fire-scarred trees have been sampled. In two cases (Rowdabaugh 1978; Swetnam and Dieterich 1985, McKenna Park), a decline in the rate of accumulation of new fires was not evident after 17 and 16 sampled trees, respectively. In these two studies, samples were dispersed over a wide area. These results suggest that 10 or more contiguous fire-scarred trees may be generally needed to identify the majority of fires in a ponderosa pine stand for estimating mean composite FI. However, the level of accuracy needed for a particular purpose really governs the sample size.

When stand-level mean composite FIs from fewer than 10 trees or less than 10 ha sampling areas are removed, the range of mean composite FIs in ponderosa pine forests is much narrower (Fig. 4a). Many of the unusual maximum FIs no longer occur (Fig. 4b), suggesting that they may be an artifact of insufficient sampling. However, after $\geq 10$ trees are sampled a new fire is still often found every few trees sampled (Fig. 7), so there is no definite endpoint. Adequate sampling does not resolve a central difficulty with the composite FI. Even after sampling $\geq 10$ trees, on average $70 \%$ or more of fires in the composite are recorded by only 1 or 2 trees, suggesting they could be small (Figs. $2 a, 2 e$, and $2 i-2 l$ ). Including all these fires lowers the mean composite FI substantially.

The mean individual-tree FI is not as sensitive as is the mean composite FI to small fires, since a small fire only affects the fire intervals on the particular tree or trees that have 
Fig. 6. Fire-history studies of ponderosa pine forests in the western United States, and the three regions used for analysis in this study. Studies are those listed in Table 4.

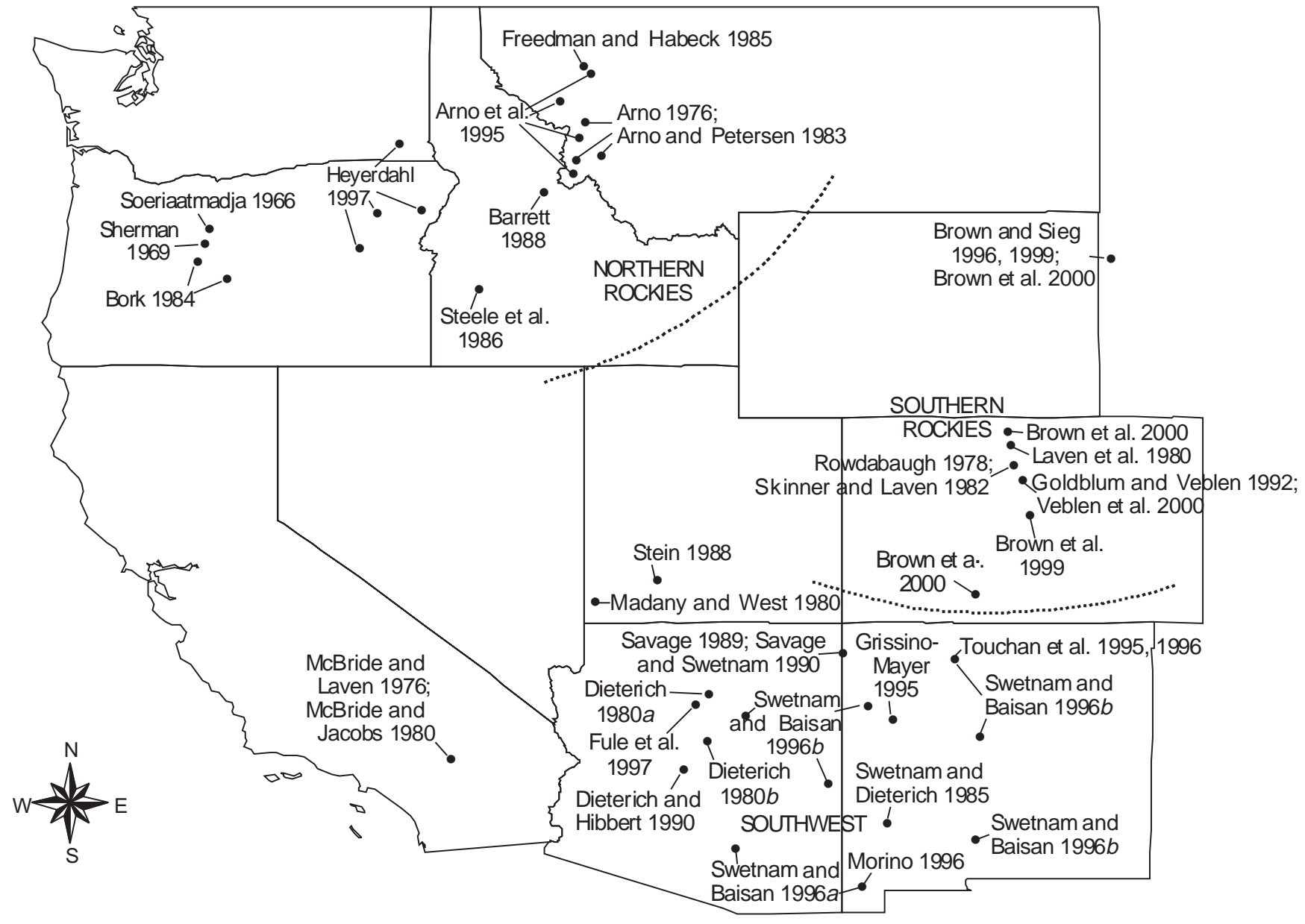

$\begin{array}{lllllll}0 & 200 & 400 & 600 & 800 & 1000 & \mathrm{~km}\end{array}$

that scar. Tree-to-tree variation in mean individual-tree FI is not so high that an adequate sample at the stand level is difficult to obtain. Power analysis (Steidl et al. 1997) suggests that sample sizes typically collected for stands or sites in fire-history studies are often sufficient to detect as little as a 25-50\% difference in mean individual-tree FI between two stands, with acceptable power, defined as >0.90 (Table 6). However, where fire intervals are short (e.g., southwestern United States), actual sample sizes are only sufficient to detect about a $50-100 \%$ difference in means with acceptable power (Table 6).

\section{Targeted sampling}

Often the primary goal of sampling has been to obtain a long and complete record of fires, particularly fires in the pre-Euro-American era. We reviewed the criteria used to select sites, stands, and sample trees in ponderosa pine studies in the western United States (Table 4). There is a widespread focus on the temporal component of the fire regime, which leads to sampling in which the following are often sought: (i) old trees with potentially long fire records, (ii) high firescar densities, (iii) trees with multiple fire scars, (iv) trees with open wounds (cat faces), and $(v)$ relict, unharvested forests (e.g., Arno and Sneck 1977; Brown and Sieg 1996; Swetnam and Baisan 1996b; Veblen et al. 2000). Swetnam and Baisan (1996a) suggest that the most efficient way to document fire history is to locate multiple-scarred trees that will result in a long fire-history record that is as complete as possible. Trees already scarred by a fire, it is argued, may be better recorders of subsequent fires because of increased susceptibility to scarring (Arno and Sneck 1977; Kilgore and Taylor 1979; Laven et al. 1980). Also, multiple-scarred trees are often older trees surrounded by fine-fuel accumulations (needles, cones, and small branches) that may increase fire intensity and, thus, it is argued, the probability of recording fires. Trees with open scars have been sought or recommended (e.g., Arno and Sneck 1977), in part because they can be removed with less damage to the tree (Kilgore and Taylor 1979), but also because the open cat face may increase the ability of the tree to record subsequent fires. Finally, in landscapes where older trees have been extensively harvested, it is possible to use the stumps in some cases (e.g., Teensma 1987; Weisberg 1999). In harvested landscapes where stumps are unusable, it may be impossible 
Fig. 7. Cumulative number of detected new fires as the number of sampled fire-scarred trees increases, for 12 stands of ponderosa pine in the western United States.

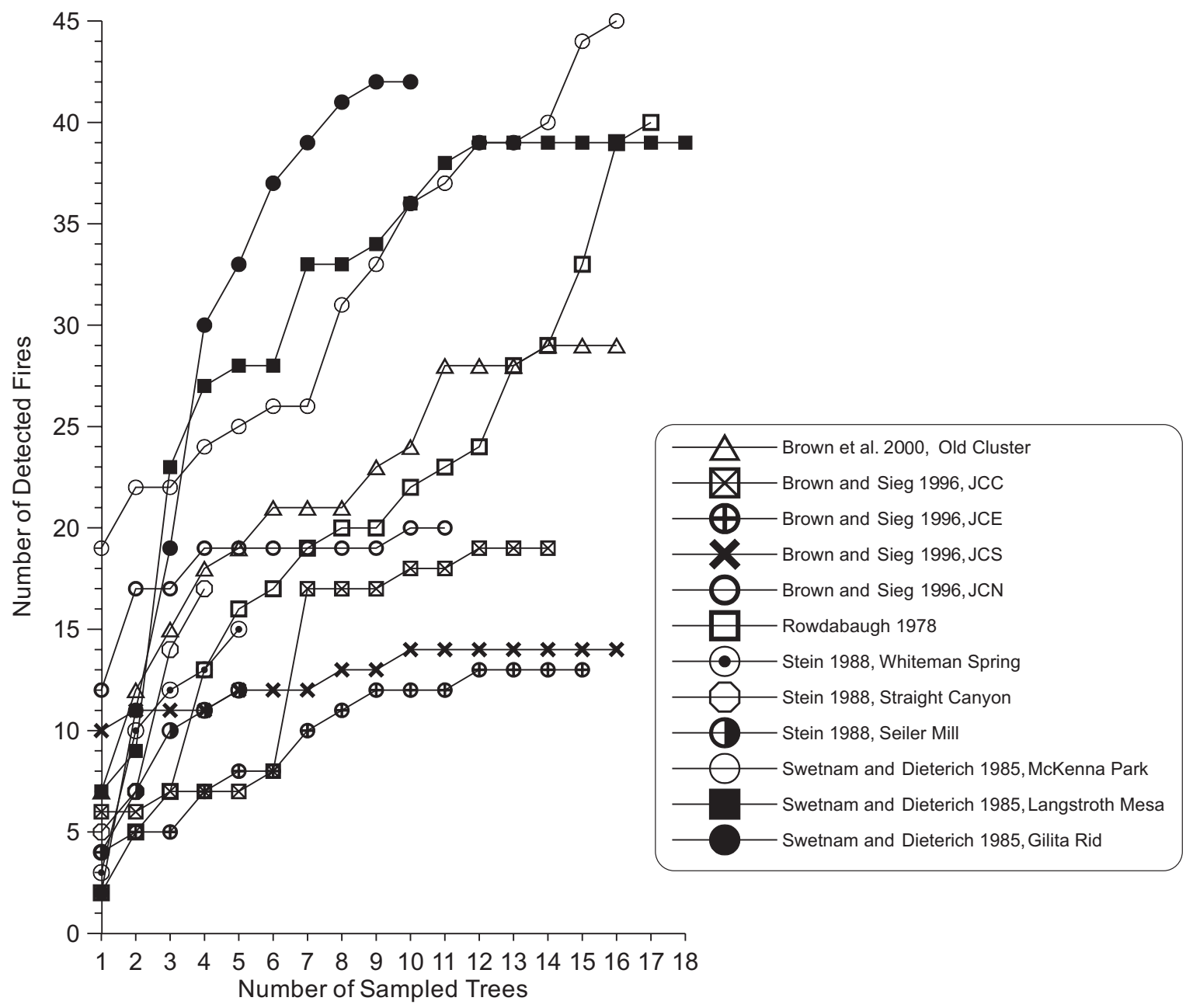

to obtain records of the pre-Euro-American fire regime without intentionally seeking relict, old ponderosa pine forests, which may only be found in isolated patches on steep slopes or in rugged topography where logging was difficult or impossible (Arno et al. 1995).

Targeting may be effective to obtain a long fire record, but targeting significantly biases the value of the sample for estimating the population mean FI and the fire rotation. Places with high scar densities and multiple-scarred trees may be places with disproportionately frequent surface fires and long periods without crown fires, since old trees that would be killed by crown fires are often sought. The places that are left out, because of this targeting, may be places with lower fire frequency or that have experienced crown fires in the recent past. Goldblum and Veblen (1992) found most fire scars in open stands or on ridges, not in dense stands. GrissinoMayer (1995) avoided sampling in the parts of a study area where there were few or no fire scars, possibly because of younger stands. These studies may be legitimate for their intended purposes (see below) but are biased if the goal is to estimate parameters of the fire regime in the whole landscape (Lorimer 1985).

For the goal of estimating the population mean FI and fire rotation for a study area, targeted sampling is "mensurative pseudoreplication" (Hurlbert 1984), because the physical sampling space is more restricted than the inference space, which is the study area as a whole. Pseudoreplication from targeting leads to a biased estimate, typically with estimated mean FI shorter than the population mean FI, and with other statistics also affected. Young or dense stands or areas with low scar densities cannot be categorically excluded from sampling if the goal is to estimate parameters of the fire regime in a study area (Lorimer 1985).

The occurrence of crown fires may be underestimated because of targeting. It is a common statement that crown fires are now more common as a result of fire suppression in ponderosa pine forests (e.g., Covington and Moore 1994b). This conclusion cannot be supported or refuted using data from most past fire-history studies in ponderosa pine forests, since the common use of targeting is biased against the detection of crown fires. Not only are the places that may have crown fires often avoided, but also the necessary data, such as treeorigin dates, are seldom collected because of a focus on long fire-scar records.

Is it targeting to restrict sampling to trees with scars? Unburned area inside a fire perimeter represents a potentially longer fire interval. Some parts of a stand may repeatedly escape burning for a variety of reasons (e.g., rocky or have lit- 
Table 6. Power analysis for scar-to-scar individual-tree FIs in ponderosa pine forest stands.

\begin{tabular}{|c|c|c|c|c|c|c|}
\hline \multirow[b]{2}{*}{ Source } & \multirow[b]{2}{*}{ Stand name } & \multirow{2}{*}{$\begin{array}{l}\text { Individual-tree } \\
\text { FI (years)* }\end{array}$} & \multirow{2}{*}{$\begin{array}{l}\text { Actual sample } \\
\text { size }(n)\end{array}$} & \multicolumn{3}{|c|}{$\begin{array}{l}\text { Sample size }(n) \text { needed to } \\
\text { detect a difference of }\end{array}$} \\
\hline & & & & $25 \%$ & $50 \%$ & $100 \%$ \\
\hline Brown et al. 1999 & Old Cluster & $75 \pm 32$ & 16 & 63 & 17 & 6 \\
\hline Brown and Sieg 1996 & $\mathrm{JCN}$ & $31 \pm 8$ & 11 & 24 & 7 & 3 \\
\hline Brown and Sieg 1996 & $\mathrm{JCC}$ & $42 \pm 9$ & 14 & 17 & 6 & 3 \\
\hline Brown and Sieg 1996 & JCE & $37 \pm 14$ & 16 & 50 & 14 & 5 \\
\hline Brown and Sieg 1996 & JCS & $32 \pm 11$ & 16 & 41 & 11 & 4 \\
\hline Dieterich $1980 a$ & Chimney Spring & $11 \pm 7$ & 7 & 138 & 36 & 10 \\
\hline Rowdabaugh 1978 & - & $40 \pm 24$ & 19 & 123 & 32 & 9 \\
\hline Stein 1988 & Whiteman Spring & $23 \pm 4$ & 5 & 12 & 4 & 3 \\
\hline Stein 1988 & Straight Canyon & $30 \pm 5$ & 4 & 11 & 4 & 3 \\
\hline Stein 1988 & Seiler Mill & $32 \pm 9$ & 5 & 28 & 8 & 4 \\
\hline Swetnam and Dieterich 1985 & McKenna Park & $13 \pm 6$ & 16 & 73 & 19 & 6 \\
\hline Swetnam and Dieterich 1985 & Langstroth Mesa & $12 \pm 7$ & 18 & 116 & 30 & 9 \\
\hline Swetnam and Dieterich 1985 & Gilita Ridge & $16 \pm 6$ & 10 & 49 & 13 & 5 \\
\hline
\end{tabular}

Note: The sample size $(n)$ needed is the number of sampled, fire-scarred trees needed to detect a particular percentage difference in mean individual-tree FI, with a statistical power of 0.90 , assuming a two-sample $t$ test to test the null hypothesis that two means do not differ.

Power analysis was completed using MINITAB release 12 (MINITAB, Inc. 1997).

$*$ Values are mean \pm SD.

tle fuel, persistently too moist to carry a surface fire, isolated by fire breaks). Parts of stands may accidentally escape fire for exceptional periods just because the pattern of fire spread is somewhat stochastic. These semi-permanent or spatially varying fire refugia may be ecologically important, allowing fire-susceptible species to persist as well as tree regeneration to occur (e.g., Greenberg and Simons 1999). Fire intervals from these parts of stands should be included in the estimate of the population mean FI and other descriptors of the fire regime (e.g., maximum fire interval) for the stand. Trees that lack scars either did not receive flames or did receive flames but resisted scarring (Table 1). If a tree did not receive flames, then its age is an estimate of the fire-free interval, subject to the same limitations as the OS interval. Some trees that lack scars thus do represent real fire-free intervals that are ecologically important.

The prevalence of unscarred trees that represent real fire intervals is dependent on the rate of scarring and the amount of unburned area. For example, consider a stand of 100 trees burned by a particular fire, in which $20 \%$ of the area inside the fire perimeter did not burn (so about 20 trees unburned). Of the remaining 80 trees, if the rate of scarring is $10 \%$, then 8 trees may be scarred and 72 unscarred even though they received flames. So 20 trees may have long fire intervals that are real and 72 may have long fire intervals that are not real, because the fire is unrecorded. For a particular tree, it is impossible to tell which is the case, so it is difficult to conceive of a correction for this problem. Sampling only scarred trees may be reasonable, given that no other solution is obvious, but this clearly biases the estimate of the mean FI against longer fire intervals. This bias is most significant when fires typically leave much unburned area inside their perimeters and the scarring rate is high. At the present time, there may be no other obvious solution than to state how the estimated parameter is affected (e.g., length of mean FI is underestimated). Additional research could help reduce the magnitude of the bias and devise potential corrections for it.
The magnitude of the effect on fire intervals from targeting is potentially large but is really uncertain, because few fire-history data have been collected without targeting. There are no published comparisons and no specific studies of targeting. Targeting multiple-scarred trees has the greatest potential for bias where the standard deviation of the individual-tree FI is large relative to the mean. This is especially the case in the southwestern United States (Table 6). In these places, there is more opportunity to find trees with atypically short fire intervals. Targeting may have less effect if fires are generally large and there is little tree-to-tree variation in fire intervals. However, we argued earlier in the paper that fires may often be small.

We investigated the potential impact of targeting multiplescarred trees, only one form of targeting, using the only available data we could find. These data are from a case study of a subalpine forest (not ponderosa pine) in southeastern Wyoming (Kipfmueller and Baker 2000), where 56 stands were searched for fire scars without targeting multiple-scarred trees. The fire rotation was estimated to be 129.7 years using reconstructed fire-year maps. If all scarred trees in 56 stands are used, mean individual-tree FI is 124 years. If only trees with two or more scars are used, then mean individual-tree FI is 79 years. If only trees with three or more scars are used, then mean individual-tree FI is 60 years. If only trees with four or more scars are used, then mean individual-tree FI is 47 years. Thus, only the mean individual-tree FI without targeting provides an accurate estimate of the fire rotation, and targeting leads to an underestimate of the fire rotation by a factor of as much as 2.6 times, if only trees with four or more scars are used. These data from a subalpine forest do not provide definitive evidence of the magnitude of bias from targeting in ponderosa pine forests, where further research is needed, although the principle is the same regardless of the dominant tree. This example suggests that targeting multiplescarred trees could significantly bias the estimate of the population mean FI, fire rotation, and other parameters. 
Table 7. Sources of change in estimates of mean fire interval, relative to composite FI estimates, in ponderosa pine forests of the western United States.

\begin{tabular}{|c|c|c|c|}
\hline Source of change & $\begin{array}{l}\text { Likely direction of change if } \\
\text { remedied }\end{array}$ & $\begin{array}{l}\text { Potential } \\
\text { magnitude }\end{array}$ & $\begin{array}{l}\text { Source of } \\
\text { estimate }\end{array}$ \\
\hline $\begin{array}{l}\text { Restricted mean composite FI } \\
\quad(>10 \% \text { scarred })\end{array}$ & Lengthen mean FI & About 1.8 times & Text \\
\hline Inclusion of OS interval & Lengthen mean FI & About 1.6 times & Fig. 5 \\
\hline Use of mean individual-tree FI & Lengthen mean FI & About 2-3 times & Fig. 8 \\
\hline Targeted sampling & Lengthen mean FI & Possibly 2-3 times & Example in text \\
\hline Adequate sample size & Narrow the range of mean FIs & Perhaps by half & Fig. $4 a$ \\
\hline
\end{tabular}

While targeting is likely to lead to biased estimates of fire intervals, there may be a need for screening to ensure that individual-tree estimates of fire intervals are good estimates. Where scars are rotten or are physically difficult or impossible to remove, screening seems legitimate and necessary, although there is a potential for bias even from this minor screening. Rotten scars may be old, and their exclusion may bias the sample against the early part of the potential record. Old, healed-over scars present the same problem. The first fire scar on a tree increases the chance that subsequent fires will be recorded as scars, but the first fire scar also increases the chance of scarring by fires that burn only one tree; these fires may be common (Fig. 2). While it may be possible to exclude scars produced by single lightning strikes on a particular tree, this screening may exclude larger fires that are recorded only on the tree that experienced the ignition. Thus, without further research it is unclear whether screening, based on recorder trees, is likely to increase or decrease the accuracy of the estimate of the population mean FI and fire rotation. Testing the effect of restriction of sampling to recorder trees is also part of the needed modern calibration.

\section{Sampling pre-Euro-American fire history}

Each fire probably removes some of the evidence of previous fires, which may create additional problems and constraints for sampling. Often a goal of fire-history studies is to reconstruct the fire intervals or other properties of the fire regime in the pre-Euro-American era. In the case of surface fires, the population from which a sample is to be drawn is the set of trees of sufficient age to record fires during that era, and presumably with fire scars from that era. Clearly, in this case, it would not be targeting to identify the trees that belong to this population and then sample them in an unbiased way (e.g., not seeking multiple-scarred trees).

The tree population from which this sample may be derived can be circumscribed spatially to estimate the land area over which the sample might be considered to estimate the population. However, if this circumscribed area does not itself span the area and environments of a particular landscape of interest, then it is impossible to draw inferences about the whole landscape (Lorimer 1985). This is the situation often confronted by fire historians. Grissino-Mayer (1995), for example, avoided sampling in the parts of a study area where there were younger stands because he was interested in the pre-Euro-American fire record that does not exist on young trees. This is not mensurative pseudoreplication in this case, but no inference can be drawn about pre-Euro-American fire intervals in the landscape as a whole. Moreover, there is evi- dence that old forests with long fire records tend to survive in atypical places in the landscape (Camp et al. 1997), perhaps where crown fires may be less likely. If so, long fire records could be inherently biased (but may not be) relative to the fire regime typical of the whole landscape. One way to analyze this potential bias is to explicitly determine how representative are the environments containing the population and sample relative to the environments in the landscape as a whole (e.g., Teensma 1987).

While fire evidence does disappear over time, and more ancient fire intervals will be more difficult to sample adequately, the same sampling adequacy requirements apply to more ancient fire intervals. If fire evidence did not disappear over time, then a researcher could obtain a pre-sample of ancient fire intervals to estimate the variability of fire intervals, then use power analysis to estimate the necessary sample size needed to detect a particular difference in mean FI with adequate power, as explained earlier. The power analysis is for a repeated measures test, rather than a $t$ test, since the same sampling units (scarred trees) often are observed over time. More ancient fire intervals are rarer, so it will likely be more difficult to obtain an adequate sample. More ancient fire intervals are likely also more spatially restricted and, thus, less certain to represent the landscape as a whole.

If the goal is a comparison between pre-Euro-American and present fire intervals, then an approximately equal sample size would be desirable, but unbalanced designs can be accommodated in statistical tests, such as repeated measures analysis (Gurevitich and Chester 1986; Shaw and MitchellOlds 1993). Thus, if dead wood is used as a source of ancient fire intervals, then an adequate sample of post-EuroAmerican fire intervals from living trees may also be needed. It is useful to display the sample size over time (e.g., Veblen et al. 2000), but also important to analyze how the spatial extent and potential spatial bias of the sample vary over time.

The composite FI presents special problems when a comparison of fire intervals over time is of interest, since composite FI typically declines as sample size increases, and the record of ancient fire intervals may be smaller. For comparing composite FIs, it seems essential to match the populations and perhaps also the samples. That is, the spatial extent of the rarer pre-Euro-American fire intervals should set the spatial extent of sampling of all intervals, so the populations are spatially matched. Then, samples of equal size, with sufficient power, from each era of interest are essential, since the estimated composite FI is affected by sample size. To achieve equal sizes, random omission of samples, if too 
Fig. 8. Distribution of fire-interval parameters for the 18 stands of ponderosa pine in the western United States with estimates of both composite FI and individual-tree FI (Table 4), comparing their $(a)$ mean composite FI, $(b)$ restricted (>10\% scarred) mean composite FI, $(c)$ restricted $(>10 \%$ scarred) mean composite FI with correction for targeting, $(d)$ mean individual-tree FI, $(e)$ mean individual-tree FI with the origin-to-scar (OS) interval, $(f)$ mean individual-tree FI with the OS interval and correction for targeting.
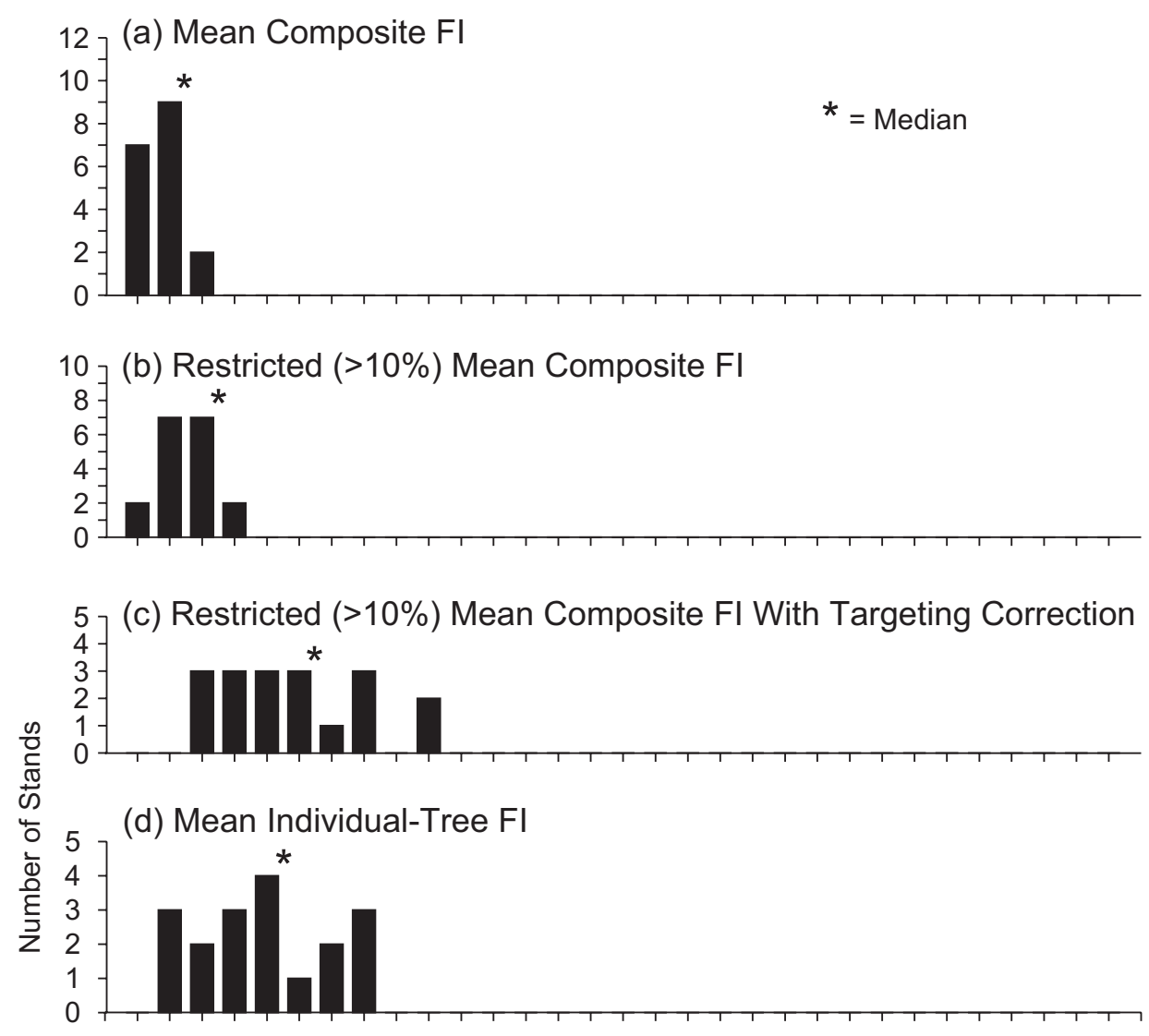

(e) Mean Individual-Tree FI With OS Interval
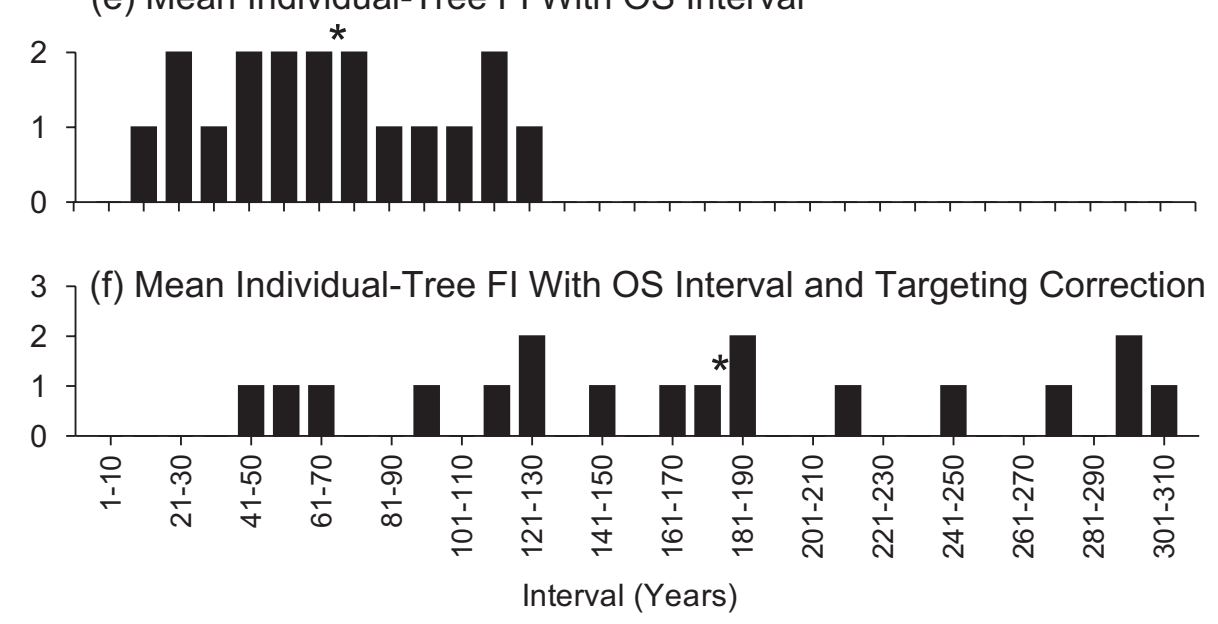

many are found for a particular era, may be necessary. With composite FI, differences in sample size or inadequate samples in particular eras may yield spurious trends.

\section{Overall assessment of uncertainties and biases}

The problems identified in this article together mean that there is considerable uncertainty about what the population mean FI and fire rotation are in ponderosa pine forests in the western United States. Much of the uncertainty comes from the problem of sampling and interpreting the fire-scar record if there are unrecorded fires. This uncertainty is present in other surface-fire regimes as well. The present magnitude of uncertainty and bias is large, because there is little research that provides the modern calibration needed to guide sampling and interpretation of the fire-history record. All the parameters (e.g., mean, median, maximum, distribution) of a 
set of fire intervals are affected by the uncertainties and biases we identified, and all the parameters should be bracketed.

What is the bracketed range of population mean FIs in ponderosa pine forests of the western United States, recognizing uncertainties and biases? Corrections are needed for several uncertainties and biases (Table 7). We suggest using the restricted $(>10 \%$ scarred) mean composite FI as the low estimate and mean individual-tree FI with OS as the high estimate of the population mean FI and fire rotation. The $10 \%$ restricted mean composite FI is on average about 1.8 times the unrestricted mean composite FI. Targeting likely decreases the mean composite FI by a factor of two to three times. Thus, on the low end of the bracketed range we suggest correcting for biases and uncertainties by multiplying mean composite FI values by 3.6 to $5.4(2 \times 1.8$ to $3 \times 1.8)$. An argument could be made that the OS interval should also be included in the correction of the mean composite FI, but we omit this correction to allow uncertainty about the OS interval. If not directly available, the mean individual-tree FI value can be estimated as typically two to three times the mean composite FI value. Addition of the OS interval increases the mean individual-tree FI value by a factor of about 1.6. Targeting likely also decreases the mean individual-tree FI by a factor of two to three times. Thus, on the high end of the bracketed range we suggest correcting for biases and uncertainties by multiplying mean composite FI values by 6.4 to $14.4(2 \times 1.6 \times 2$ to $3 \times 1.6 \times 3)$. The population mean FIs and fire rotations for ponderosa pine forests in the western United States may thus lie in a large range, spanning 3.6 to 14.4 times the unrestricted mean composite FI values.

A sample of the effect of these corrections can be obtained by using the 18 stands for which both mean composite FI and mean individual-tree FI estimates are available (Table 4). We use only those stands with 10 or more trees sampled. In this sample, mean composite FI varies from 5 to 21 years (Fig. 8a), which is very similar to the overall range for the studies in Table 4 (see Fig. $4 a$ ). We estimate the restricted $(>10 \%)$ mean composite FI for each stand (Fig. $8 b$ ), using the average correction of 1.8 found in our earlier analysis, as the authors of these studies did not use a restriction. The mean individual-tree FI with OS is estimated (Fig. 8e) using the mean individual-tree FI (Fig. 8d) and the regression equation (Fig. 6). Finally, we correct for targeting by applying a multiplicative correction of 2.5 times (Figs. $8 c$ and $8 f$ ). Thus, the 18 stands have a reported mean FI range of 5-21 years (median 11.5 years), but the bracketed range of the population mean FI is from 22.5 to 94.5 years (median 51.8 years) on the low end and from 48.0 to 308.0 years (median 170.0 years) on the high end (Fig. 8).

Uncertainty about unrecorded fires means that this bracketing cannot presently be narrowed. Research is first needed to complete the modern calibration of the fire-scar signal relative to the actual fire regime. Such a research program can probably narrow the range of some uncertainties. We propose below some methods to minimize biases. Until research addresses the uncertainties and biases, it is necessary to acknowledge the large range within which the population mean FIs and fire rotations may lie. While we have not presented comparable bracketing for other parameters (e.g., maximum fire interval), the same kind of analysis is appro- priate. It may be optimistic, however, to expect that it will ever be possible to have very accurate estimates of fire intervals in the pre-Euro-American landscape. There will always be some unresolvable uncertainty that, in our opinion, is best treated by providing bracketed estimates.

There is presently insufficient research to be able to propose remedies for all the potential problems we have identified, but we have some suggestions. First, where possible, use a statistically valid and unbiased approach (e.g., random, stratified random) to locate potential stands for sampling. If unbiased sampling is not possible, because the study area contains only a few remnant stands (e.g., unlogged) suitable for sampling, then include them all or randomly choose a sample of them. In either case, determine to what extent the sample is representative of the spectrum of physical and biological settings that were present in the landscape (e.g., Teensma 1987). Second, determine whether the potential sampling location was subject to a crown fire, a surface fire, or both. Third, use a pre-sample and power analysis to estimate the sample size needed and collect at least the minimum sample of fire-scarred trees from a contiguous area. Use minimum screening standards (e.g., no damage, physically possible to remove) but without selecting trees based on other criteria that may bias the sample. Whenever possible, obtain an estimate of the pith date near the root collar of the tree from which the scar was obtained, so that the OS interval can be estimated. Finally, bracket the possible range of the population mean FI and fire rotation using the restricted $(>10 \%)$ mean composite FI and mean individual-tree FI with OS. Bracket other parameters (e.g., maximum fire interval, distribution of fire intervals) as well.

\section{Implications for ponderosa pine forests}

The uncertainty we identify in fire-history results suggests that present concepts of the role of fire in maintaining the structure of ponderosa pine forests are less certain. Surface fire is still very important to these forests. However, the longer mean FIs and fire rotations that certainly occurred, and the spatially patchy nature of fire, somewhat diminish the magnitude of control of forest structure by fire relative to present conceptions of fire's importance in ponderosa pine forests. A logical conclusion is that other factors, such as climatic changes, timber harvesting, and domestic livestock grazing, may have played a somewhat larger role than previously thought in post-Euro-American change in these forests (e.g., Savage and Swetnam 1990; Grissino-Mayer 1995; Savage et al. 1996). It is less possible, for example, to exclude the hypothesis that past climate (e.g., cold, dry Little Ice Age), no longer present, may have played a role in shaping the open, low-density forest structure present in lowelevation forests at the time of Euro-American settlement, an idea that has been suggested for other ecosystems (Clark 1990). Ponderosa pine regeneration, in particular, is known to be sensitive to climatic conditions (e.g., Savage et al. 1996).

Longer fire rotations and spatially patchy fires also suggest that a greater diversity of forest structures probably existed in the pre-Euro-American ponderosa pine landscape, possibly leading to some crown fires. Dense thickets of regenerating trees or dense old patches of trees may have been 
a part of the pre-Euro-American ponderosa pine forest landscape (e.g., Shinneman and Baker 1997), since there is more opportunity for these to have occurred. Both modeling studies (Roberts and Betz 1999) and empirical research in other pine landscapes (Greenberg and Simons 1999) suggest that longer fire-free intervals allow greater diversity of forest structures. The possibility of patches of regenerating trees and dense patches of older trees also implies greater likelihood that stand-replacing crown fires were a part of the processes shaping the pre-Euro-American ponderosa pine forest landscape (Shinneman and Baker 1997). Dense forests may be important for the Mexican spotted owl in some southwestern ponderosa pine landscapes (Ganey et al. 1999). Because of this variability in forest structure and its potential importance to wildlife, widespread intentional restoration of low-density forest structure across the landscape (e.g., Covington et al. 1997; Fulé et al. 1997) is unwarranted.

Surface fires, however, were clearly an important process in these forests, and there is also ample evidence that fires have been excluded by human land uses (e.g., Savage and Swetnam 1990). Exclusion of surface fires undoubtedly has altered forest structure, since surface fires readily kill young trees (Table 3). However, the magnitude of the impact of fire exclusion on ponderosa pine forests is uncertain because of uncertainty about mean FIs and fire rotations. Some parts of these forests need fire intervals of 50 or more years for tree regeneration to succeed.

Since there is large uncertainty about the fire regime in ponderosa pine forests, caution is warranted until some uncertainty can be removed. We suggest that restoration of fire as a process is certainly warranted, but quantitative targets for how frequent prescribed fires should be, how much land area should be burned in a particular year, or how much fuel reduction is appropriate (Babbitt 1997; Laverty and Williams 2000) are premature because of large uncertainty about mean fire intervals and fire rotations. More careful study is also warranted before physical restoration of forest structure or fuels is undertaken on a wide scale (Covington 2000; Laverty and Williams 2000). This is particularly true in valuable National Parks, Research Natural Areas, and other protected areas, where a goal is often to maintain natural ecosystems and the species dependent upon them.

\section{Acknowledgments}

This research was supported in part by the U.S. Geological Survey, Biological Resources Division, under Cooperative Agreement No. 1434-HQ-97-RU-01542. Reviews by James K. Agee, Peter Brown, Henri Grissino-Mayer, E.A. Johnson, Melissa Savage, Carl Skinner, Thomas W. Swetnam, Thomas T. Veblen, and Peter J. Weisberg significantly improved the manuscript.

\section{References}

Agee, J.K. 1993. Fire ecology of Pacific Northwest forests. Island Press, Washington, D.C.

Arno, S.F. 1976. The historical role of fire on the Bitterroot National Forest. USDA For. Serv. Res. Pap. INT-187.
Arno, S.F., and Petersen, T.D. 1983. Variation in estimates of fire intervals: a closer look at fire history on the Bitterroot National Forest. USDA For. Serv. Res. Pap. INT-301.

Arno, S.F., and Sneck, K.M. 1977. A method for determining fire history in coniferous forests of the mountain west. USDA For. Serv. Gen. Tech. Rep. INT-42.

Arno, S.F., Scott, J.H., and Hartwell, M.G. 1995. Age-class structure of old growth ponderosa pine/Douglas-fir stands and its relationship to fire history. USDA For. Serv. Res. Pap. INT-RP-481.

Babbitt, B. 1997. A coordinated campaign: fight fire with fire. Remarks of Secretary of the Interior, Bruce Babbitt (Tuesday, February 11, 1997). Boise State University, Boise, Idaho.

Barrett, S.W. 1988. Fire suppression's effects on forest succession within a central Idaho wilderness. West. J. Appl. For. 3: 76-80.

Bock, J.H., and Bock, C.E. 1984. Effect of fires on woody vegetation in the pine-grassland ecotone of the southern Black Hills. Am. Midl. Nat. 112: 35-42.

Bork, J.L. 1984. Fire history in three vegetation types on the eastern side of the Oregon Cascades. Ph.D. dissertation, Oregon State University, Corvallis.

Brown, P.M., and Sieg, C.H. 1996. Fire history in interior ponderosa pine communities of the Black Hills, South Dakota, USA. Int. J. Wildland Fire, 6: 97-105.

Brown, P.M., and Sieg, C.H. 1999. Historical variability in fire at the ponderosa pine - northern Great Plains prairie ecotone, southeastern Black Hills, South Dakota. Ecoscience, 6: 539-547.

Brown, P.M., Kaufmann, M.R., and Shepperd, W.D. 1999. Longterm, landscape patterns of past fire events in a montane ponderosa pine forest of central Colorado. Landsc. Ecol. 14: 513-532.

Brown, P.M., Ryan, M.G., and Andrews, T.G. 2000. Historical surface fire frequency in ponderosa pine stands in research natural areas, central Rocky Mountains and Black Hills, USA. Nat. Areas J. 20: 133-139.

Camp, A., Oliver, C., Hessburg, P., and Everett, R. 1997. Predicting late-successional fire refugia pre-dating European settlement in the Wenatchee Mountains. For. Ecol. Manage. 95: 63-77.

Clark, J.S. 1988. Particle motion and the theory of charcoal analysis: source area, transport, deposition, and sampling. Quat. Res. 30: $67-80$.

Clark, J.S. 1990. Fire and climate during the last $750 \mathrm{yr}$ in northwestern Minnesota. Ecol. Monogr. 60: 135-159.

Cooper, C.F. 1960. Changes in vegetation, structure and growth of southwestern pine forests since white settlement. Ecol. Monogr. 30: $129-164$.

Covington, W.W. 2000. Helping western forests heal: the prognosis is poor for US forest ecosystems. Nature (London), 408: 135-136.

Covington, W.W., and Moore, M.M. 1992. Postsettlement changes in natural fire regimes: implications for restoration of oldgrowth ponderosa pine forests. In Old-growth Forests in the Southwest and Rocky Mountain Regions: Proceedings of a Workshop, 9-13 Mar. 1992, Portal, Ariz. Edited by M.R. Kaufmann, W.H. Moir, and R.L. Bassett. USDA For. Serv. Gen. Tech. Rep. RM-213. pp. 81-99.

Covington, W.W., and Moore, M.M. 1994a. Postsettlement changes in natural fire regimes and forest structure: ecological restoration of old-growth ponderosa pine forests. In Assessing forest ecosystem health in the inland West. Edited by R.N. Sampson and D.L. Adams. Food Products Press, New York. pp. $13-63$.

Covington, W.W., and Moore, M.M. 1994b. Southwestern ponderosa pine forest structure: changes since Euro-American settlement. J. For. 92: 39-47.

Covington, W.W., Fulé, P.Z., Moore, M.M., Hart, S.C., Kolb, T.E., Mast, J.N., Sackett, S.S., and Wagner, M.R. 1997. Restoring 
ecosystem health in ponderosa pine forests of the southwest. J. For. 95: 23-29.

Davis, J.R. 1965. A survey of an intentional burn in Arizona ponderosa pine. USDA For. Serv. Res. Note RM-41.

Dieterich, J.H. 1980a. Chimney Spring forest fire history. USDA For. Serv. Gen. Tech. Rep. RM-220.

Dieterich, J.H. 1980b. The composite fire interval-a tool for more accurate interpretation of fire history. In Proceedings of the Fire History Workshop. Edited by M.A. Stokes and J.H. Dieterich. USDA For. Serv. Gen. Tech. Rep. RM-81. pp. 8-14.

Dieterich, J.H., and Hibbert, A.R. 1990. Fire history in a small ponderosa pine stand surrounded by chaparral. In Effects of Fire Management of Southwestern Natural Resources: Proceedings of the Symposium, 15-17 Nov. 1988, Tucson, Ariz. Edited by J.S. Krammes. USDA For. Serv. Gen. Tech. Rep. RM-191. pp. 168-173.

Dieterich, J.H., and Swetnam, T.W. 1984. Dendrochronology of a fire-scarred ponderosa pine. For. Sci. 30: 238-247.

Draper, N.R., and Smith, H. 1981. Applied regression analysis. 2nd ed. John Wiley \& Sons, New York.

Fahnestock, G.R., and Hare, R.C. 1964. Heating of tree trunks in surface fires. J. For. 62: 799-805.

Fisher, R.F., Jenkins, M.J., and Fisher, W.F. 1987. Fire and the prairie-forest mosaic of Devils Tower National Monument. Am. Midl. Nat. 117: 250-257.

Freedman, J.D., and Habeck, J.R. 1985. Fire, logging, and whitetailed deer interrelationships in the Swan Valley, northwestern Montana. In Fire's Effects on Wildlife Habitat-Symposium Proceedings. Edited by J.E. Lotan and J.K. Brown. USDA For. Serv. Gen. Tech. Rep. INT-186. pp. 23-35.

Fulé, P.Z., Covington, W.W., and Moore, M.M. 1997. Determining reference conditions for ecosystem management of southwestern ponderosa pine forests. Ecol. Appl. 7: 895-908.

Gaines, E.M., Kallander, H.R., and Wagner, J.A. 1958. Controlled burning in southwestern ponderosa pine: results from the Blue Mountain plots, Fort Apache Indian Reservation. J. For. 56: 323-327.

Ganey, J.L., Block, W.M., Jenness, J.S., and Wilson, R.A. 1999. Mexican spotted owl home range and habitat use in pine-oak forest: implications for forest management. For. Sci. 45: 127-135.

Gartner, F.R., and Thompson, W.W. 1973. Fire in the Black Hills forest-grass ecotone. Proc. Tall Timbers Fire Ecol. Conf. 12: $37-68$.

Gill, A.M. 1974. Toward an understanding of fire-scar formation: field observation and laboratory simulation. For. Sci. 20: 198-205.

Goldblum, D., and Veblen, T.T. 1992. Fire history of a ponderosa pine - Douglas-fir forest, Colorado Front Range. Phys. Geogr. 13: $133-148$.

Gordon, D.T. 1967. Prescribed burning in the interior ponderosa pine type of northeastern California ... a preliminary study. USDA For. Serv. Res. Pap. PSW-45.

Greenberg, C.H., and Simons, R.W. 1999. Age, composition, and stand structure of old-growth oak sites in the Florida high pine landscape: implications for ecosystem management and restoration. Nat. Areas J. 19: 30-40.

Grissino-Mayer, H.D. 1995. Tree-ring reconstructions of climate and fire history at El Malpais National Monument, New Mexico. Ph.D. dissertation. University of Arizona, Tucson.

Grissino-Mayer, H.D. 2000. Modeling fire interval data from the American Southwest with the Weibull distribution. Int. J. Wildland Fire, 9: 37-50.

Gurevitich, J., and Chester, S.T., Jr. 1986. Analysis of repeated measures experiments. Ecology, 67: 251-255.
Gutsell, S.L., and Johnson, E.A. 1996. How fire scars are formed: coupling a disturbance process to its ecological effect. Can. J. For. Res. 26: 166-174.

Heyerdahl, E.K. 1997. Spatial and temporal variation in historical fire regimes of the Blue Mountains, Oregon and Washington: the influence of climate. Ph.D. dissertation, University of Washington, Seattle.

Hurlbert, S.H. 1984. Pseudoreplication and the design of ecological field experiments. Ecol. Monogr. 54: 187-211.

Johnson, E.A., and Gutsell, S.L. 1994. Fire frequency models, methods and interpretations. Adv. Ecol. Res. 25. pp. 239-287.

Keeley, J.E., and Stephenson, N.L. 2000. Restoring natural fire regimes in the Sierra Neveda in an era of global change. In Wilderness Science in a Time of Change Conference. Edited by D.N. Cole and S.F. McCool. USDA For. Ser. Proc. RMRS-P-15. Vol. 5. pp. 255-265.

Kilgore, B.M., and Taylor, D. 1979. Fire history of a sequoia mixed conifer forest. Ecology, 60: 129-142.

Kipfmueller, K.F., and Baker, W.L. 2000. A fire history of a subalpine forest in south-eastern Wyoming, USA. J. Biogeogr. 27: 71-85.

Lachmund, H.G. 1923. Relative susceptibility of incense cedar and yellow pine to bole injury in forest fires. J. For. 21: 815-817.

Laven, R.D., Omi, P.N., Wyant, J.G., and Pinkerton, A.S. 1980. Interpretation of fire scar data from a ponderosa pine ecosystem in the central Rocky Mountains, Colorado. In Proceedings of the Fire History Workshop. Edited by M.A. Stokes and J.H. Dieterich. USDA For. Serv. Gen. Tech. Rep. RM-81. pp. 46-49.

Laverty, L., and Williams, J. 2000. Protecting people and sustaining resources in fire-adapted ecosystems: a cohesive strategy. USDA Forest Service, Washington, D.C.

Lindenmuth, A.W., Jr. 1962. Effects on fuels and trees of a large intentional burn in ponderosa pine. J. For. 60: 804-810.

Lorimer, C.G. 1985. Methodological considerations in the analysis of forest disturbance history. Can. J. For. Res. 15: 200-213.

Madany, M.H., and West, N.E. 1980. Fire history of two montane forest areas of Zion National Park. In Proceedings of the Fire History Workshop. Edited by M.A. Stokes and J.H. Dieterich. USDA For. Serv. Gen. Tech. Rep. RM-81. pp. 50-56.

McBride, J.R. 1983. Analysis of tree rings and fire scars to establish fire history. Tree-Ring Bull. 43: 51-67.

McBride, J.R., and Jacobs, D.F. 1980. Land use and fire history in the mountains of southern California. In Proceedings of the Fire History Workshop. Edited by M.A. Stokes and J.H. Dieterich. USDA For. Serv. Gen. Tech. Rep. RM-81. pp. 85-88.

McBride, J.R., and Laven, R.D. 1976. Scars as an indicator of fire frequency in the San Bernardino Mountains, California. J. For. 74: 439-442.

McKelvey, K.S., Skinner, C.N., Chang, C.-R., Erman, D.C., Husari, S.J., Parsons, D.J., van Wagtendonk, J.W., and Weatherspoon, C.W. 1996. An overview of fire in the Sierra Nevada. In Sierra Nevada Ecosystem Project: final report to Congress. Vol. 2. Assessments and scientific basis for management options. University of California, Davis. pp. 1033-1040.

MINITAB, Inc. 1997. MINITAB, release 12 edition. MINITAB, State College, $\mathrm{Pa}$.

Morino, K.A. 1996. Reconstruction and interpretation of historical patterns of fire occurrence in the Organ Mountains, New Mexico. M.S. thesis, University of Arizona, Tucson.

Morris, W.G., and Mowat, E.L. 1958. Some effects of thinning a ponderosa pine thicket with a prescribed fire. J. For. 56: 203-209.

Roberts, D.W., and Betz, D.W. 1999. Simulating landscape vegetation dynamics of Bryce Canyon National Park with the vital attributes/fuzzy systems model VAFS/LANDSIM. In Spatial 
modeling of forest landscape change: approaches and applications. Edited by D.J. Mladenoff and W.L. Baker. Cambridge University Press, Cambridge, U.K. pp. 99-124.

Romme, W. 1980. Fire history terminology: report of the ad hoc committee. In Proceedings of the Fire History Workshop. Edited by M.A. Stokes and J.H. Dieterich. USDA For. Serv. Gen. Tech. Rep. RM-81. pp. 135-137.

Rowdabaugh, K.M. 1978. The role of fire in the ponderosa pinemixed conifer ecosystems. M.S. thesis, Colorado State University, Fort Collins.

Sackett, S.S. 1980. Reducing natural ponderosa pine fuels using prescribed fire: two case studies. USDA For. Serv. Res. Note RM-392.

Sackett, S.S. 1984. Observations on natural regeneration in ponderosa pine following a prescribed fire in Arizona. USDA For. Serv. Res. Note RM-435.

Sackett, S.S., Haase, S.M., and Harrington, M.G. 1996. Lessons learned from fire use for restoring southwestern ponderosa pine ecosystems. In Conference on Adaptive Ecosystem Restoration and Management: Restoration of Cordilleran Conifer Landscapes of North America. Edited by W. Covington and P.K. Wagner. USDA For. Serv. Gen. Tech. Rep. RM-GTR-278. pp. 54-61.

Savage, M. 1989. Structural dynamics of a pine forest in the American Southwest under chronic human disturbance. Ph.D. Dissertation, University of Colorado, Boulder.

Savage, M., and Swetnam, T.W. 1990. Early 19th-century fire decline following sheep pasturing in a Navajo ponderosa pine forest. Ecology, 71: 2374-2378.

Savage, M., Brown, P.M., and Feddema, J. 1996. The role of climate in a pine forest regeneration pulse in the southwestern United States. Ecoscience, 3: 310-318.

Shaw, R.G., and Mitchell-Olds, T. 1993. ANOVA for unbalanced data: an overview. Ecology, 74: 1638-1645.

Sherman, R.J. 1969. Spatial and developmental patterns of the vegetation of Black Butte, Oregon. Ph.D. dissertation, Oregon State University, Corvallis.

Shinneman, D.J., and Baker, W.L. 1997. Nonequilibrium dynamics between catastrophic disturbances and old-growth forests in ponderosa pine landscapes of the Black Hills. Conserv. Biol. 11: 1276-1288.

Show, S.B., and Kotok, E.I. 1924. The role of fire in the California pine forests. U.S. Dep. Agric. Bull. 1294.

Skinner, T., and Laven, R.D. 1982. Final report: background data for natural fire management in Rocky Mountain National Park. Unpublished report to Rocky Mountain National Park, Contract CX 1200-1-B020. Department of Forest and Wood Sciences, Colorado State University, Fort Collins.

Soeriaatmadja, R.E. 1966. Fire history of the ponderosa pine forests of the Warm Springs Indian Reservation, Oregon. Ph.D. Dissertation. Oregon State University, Corvallis.

Steele, R., Arno, S.F., and Geier-Hayes, K. 1986. Wildfire patterns change in central Idaho's ponderosa pine - Douglas-fir forest. West. J. Appl. For. 1: 16-18.

Steidl, R.J., Hayes, J.P., and Schauber, E. 1997. Statistical power analysis in wildlife research. J. Wildl. Manage. 61: 270-279.

Stein, S.J. 1988. Fire history of the Paunsaugunt Plateau in southern Utah. Great Basin Nat. 48: 58-63.
Strauss, D., Bednar, L., and Mees, R. 1989. Do one percent of forest fires cause ninety-nine percent of the damage? For. Sci. 35: 319-328.

Swetnam, T.W., and Baisan, C.H. 1996a. Historical fire regime patterns in the southwestern United States since AD 1700. In Fire Effects in Southwestern Forests: Proceedings of the Second La Mesa Fire Symposium. Edited by C. D. Allen. USDA For. Serv. Gen. Tech. Rep. RM-GTR-286. pp. 11-32.

Swetnam, T.W., and Baisan, C.H. 1996b. Fire histories of montane forests in the Madrean Borderlands. In Effects of fire on Madrean Province ecosystems. Edited by P.F. Pfolliott, L.F. DeBano, M.B. Baker, Jr., G.J. Gottfried, G. Solis-Garza, C.B. Edminister, D.G. Neary, L.S. Allen, and R.H. Hamre. USDA For. Serv. Gen. Tech. Rep. RM-GTR-289. pp. 15-36.

Swetnam, T.W., and Dieterich, J.H. 1985. Fire history of ponderosa pine forests in the Gila Wilderness, New Mexico. In Proceedings-Symposium and Workshop on Wilderness Fire. Edited by J.E. Lotan, B.M. Kilgore, W.C. Fischer, and R.W. Mutch. USDA For. Serv. Gen. Tech. Rep. INT-182. pp. 390-397.

Taylor, A.R. 1969. Tree-bole ignition in superimposed lightning scars. USDA For. Serv. Res. Note INT-90.

Teensma, P.D.A. 1987. Fire history and fire regimes of the central western Cascades of Oregon. University of Oregon, Eugene.

Touchan, R., Swetnam, T.W., and Grissino-Mayer, H.D. 1995. Effects of livestock grazing on pre-settlement fire regimes in New Mexico. In Proceedings: Symposium on Fire in Wilderness and Park Management. Edited by J.K. Brown, R.W. Mutch, C.W. Spoon, and R.H. Wakimoto. USDA For. Serv. Gen. Tech. Rep. INT-GTR-320. pp. 268-272.

Touchan, R., Allen, C.D., and Swetnam, T.W. 1996. Fire history and climatic patterns in ponderosa pine and mixed-conifer forests of the Jemez Mountains, northern New Mexico. In Fire Effects in Southwestern Forests: Proceedings of the Second La Mesa Fire Symposium. Edited by C.D. Allen. USDA For. Serv. Gen. Tech. Rep. RM-GTR-286. pp. 33-46.

Veblen, T.T., Kitzberger, T., and Donnegan, J. 1996. Fire ecology in the wildland/urban interface of Boulder County. A research report to the City of Boulder Open Space. Department of Geography, University of Colorado, Boulder.

Veblen, T.T., Kitzberger, T., and Donnegan, J. 2000. Climatic and human influences on fire regimes in the Colorado Front Range. Ecol. Appl. 10: 1178-1195.

Vines, R.G. 1968. Heat transfer through bark, and the resistance of trees to fire. Aust. J. Bot. 16: 499-514.

Weaver, H.A. 1947. Fire-nature's thinning agent in ponderosa pine stands. J. For. 45: 437-444.

Weaver, H.A. 1951. Fire as an ecological factor in the southwestern ponderosa pine forests. J. For. 49: 93-98.

Weaver, H.A. 1959. Ecological changes in the ponderosa pine forests of the Warm Springs Indian Reservation in Oregon. J. For. 57: $15-20$.

Weisberg, P.J. 1999. Fire history, fire regimes, and development of forest structures in the central western Cascades. Ph.D. dissertation, Oregon State University, Corvallis.

White, A.S. 1985. Presettlement regeneration patterns in a southwestern ponderosa pine stand. Ecology, 66: 589-594.

Wooldridge, D.D., and Weaver, H. 1965. Some effects of thinning a ponderosa pine thicket with a prescribed fire, II. J. For. 63: 92-95. 